\title{
Reconstruction of MIS 5 climate in the central Levant using a stalagmite from Kanaan Cave, Lebanon
}

\author{
C. Nehme ${ }^{1,2}$, S. Verheyden ${ }^{1,2}$, S. R. Noble ${ }^{3}$, A. R. Farrant ${ }^{4}$, D. Sahy ${ }^{4}$, J. Hellstrom ${ }^{5}$, J. J. Delannoy ${ }^{6}$, and P. Claeys ${ }^{2}$ \\ ${ }^{1}$ Department of Earth and History of Life, Royal Institute of Natural Sciences (RBINS), Brussels, Belgium \\ ${ }^{2}$ Analytical, Environmental \& Geo-Chemistry, Department of Chemistry, Faculty of Sciences, \\ Vrije Universiteit Brussel, Brussels, Belgium \\ ${ }^{3}$ NERC Isotope Geosciences Laboratory, Keyworth, Nottingham, NG12 5GG, UK \\ ${ }^{4}$ British Geological Survey, Keyworth, Nottingham, NG12 5GG, UK \\ ${ }^{5}$ Geochemistry Laboratory, Earth Science Department, University of Melbourne, Melbourne, Australia \\ ${ }^{6}$ Laboratoire EDYTEM UMR5204 CNRS, Université de Savoie, Bourget-du-Lac, France
}

Correspondence to: C. Nehme (carole.nehme@naturalsciences.be)

Received: 17 June 2015 - Published in Clim. Past Discuss.: 17 July 2015

Revised: 26 November 2015 - Accepted: 7 December 2015 - Published: 21 December 2015

\begin{abstract}
Lying at the transition between the temperate Mediterranean domain and subtropical deserts, the Levant is a key area to study the palaeoclimatic response over glacialinterglacial cycles. This paper presents a precisely dated last interglacial (MIS 5) stalagmite (129-84 ka) from the Kanaan Cave, Lebanon. Variations in growth rate and isotopic records indicate a warm humid phase at the onset of the last interglacial at $\sim 129 \mathrm{ka}$ that lasted until $\sim 125 \mathrm{ka}$. A gradual shift in speleothem isotopic composition (125$122 \mathrm{ka}$ ) is driven mainly by the $\delta^{18} \mathrm{O}$ source effect of the eastern Mediterranean surface waters during sapropel 5 (S5). The onset of glacial inception began after $\sim 122 \mathrm{ka}$, interrupted by a short wet pulse during the sapropel 4 (S4) event. Low growth rates and enriched oxygen and carbon values until $\sim 84 \mathrm{ka}$ indicate a transition to drier conditions during Northern Hemisphere glaciation.
\end{abstract}

\section{Introduction}

Located at the interface between mid- and high-latitude climate systems, and affected by both the North Atlantic Oscillation and the monsoonal system over Africa, the Levant region (eastern Mediterranean Basin) has the unique potential to record the occurrence of climatic changes in both systems. Known for its long record of prehistoric human settlements, the Levant straddles the transition zone be- tween the more humid Mediterranean climate in the north and the arid Saharo-Arabian desert climate regime in the south. This transition zone is characterized by steep precipitation and temperature gradients. Over the past decade, several studies have attempted to understand the palaeoclimate of this critical region (Fig. 1a) using both marine (Kallel et al., 1997; Rossignol-Strick and Paterne, 1999; Emeis et al., 2003) and continental palaeoclimate records (Frumkin et al., 2000; Bar-Matthews et al., 2003; Kolodny et al., 2005; Develle et al., 2011; Ayalon et al., 2013; Vaks et al., 2010; Gasse et al., 2015). A key period for understanding the climate system in the Levant is the last interglacial: Marine Isotope Stage (MIS) 5. This is generally considered to be a warm period, comparable to the presentday climate, although this is still under considerable debate (Vaks et al., 2003; Lisker et al., 2010; Ayalon et al., 2002, 2013; Bar-Matthews, 2014). However, discrepancies between different palaeoclimate archives exist, particularly between speleothem and lacustrine archives. In particular, inconsistencies between records from the Negev Desert (Vaks et al., 2003, 2006), central Israel/Palestine (Bar-Matthews et al., 2000, 2003; Frumkin et al., 2000), and Lebanon (Develle et al., 2011; Gasse et al., 2011, 2015), as well as between the eastern Mediterranean coastline (Ayalon et al., 2013) and inner basins (e.g. Dead Sea basin, DSB; Kolodny et al., 2005; Enzel et al., 2008; Lisker at al., 2010), are evident. In particular, speleothem isotopic records of Soreq, Peqiin, and West 


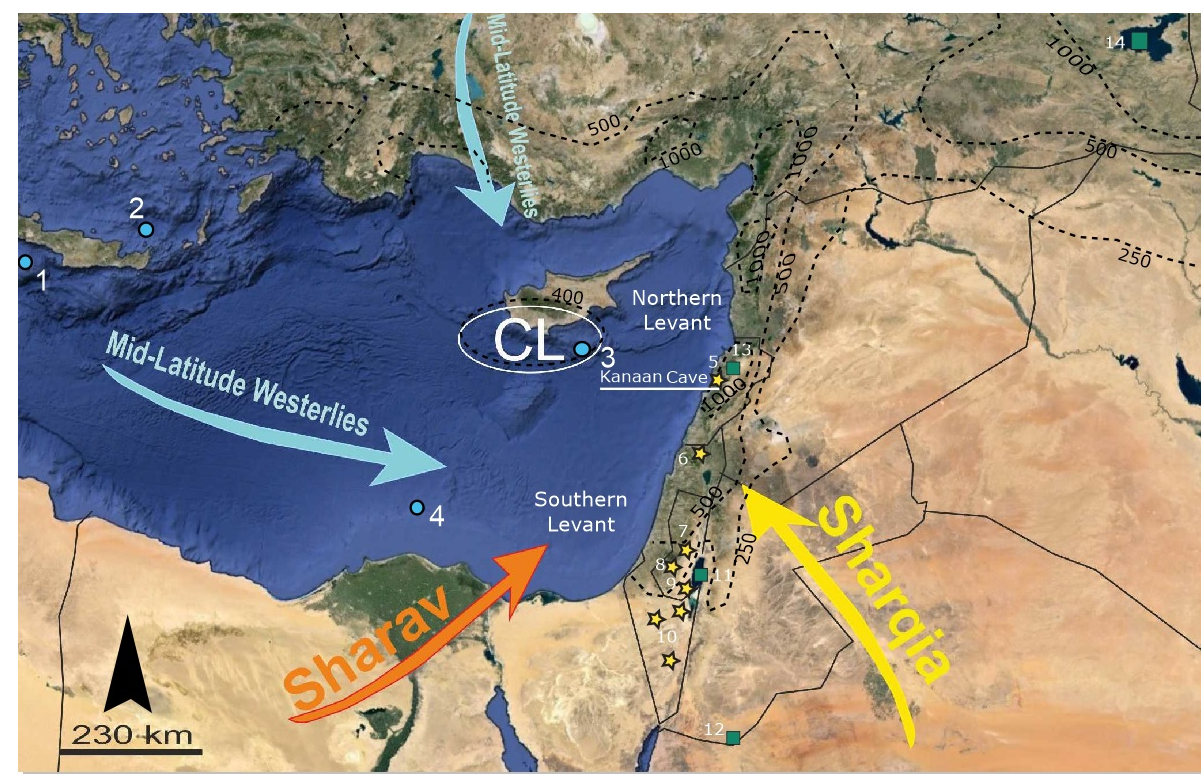

Figure 1. The eastern Mediterranean showing the location of palaeoclimate records including this study and the major wind trajectories (Saaroni et al., 1998), including the mid-latitude westerlies, and occasional incursions from the Sharav cyclone and the Sharqiya. The northsouth and east-west precipitation gradients are indicated by dashed dark lines (isohyets in mm). CL: Cyprus Low. The locations of Kanaan Cave and other Levantine palaeoclimatic records spanning the MIS 5 period cited in the text are numbered 1 to 14 . Records derived from marine studies are indicated by points, lake level reconstructions and pollen data by rectangles, and speleothems by stars. (1) Core MD 70-41 (Emeis et al., 2003); (2) core LC21 (Grant et al., 2012); (3) core ODP Site 967 (Rohling et al., 2002, 2004; Emeis et al., 2003; Scrivner et al., 2004); (4) core ODP Site 968 (Ziegler et al., 2010); (5) Kanaan Cave; (6) Peqiin Cave (Bar-Matthews et al., 2003); (7) West Jerusalem Cave (Frumkin et al., 1999, 2000); (8) Soreq Cave (Bar-Matthews et al., 2000, 2003); (9) Tsavoa Cave (Vaks et al., 2006, 2013); (10) Negev composite speleothems from Ashalim, Hol-Zakh, and Ma'ale-ha-Meyshar caves (Vaks et al., 2010); (11) lakes of the Dead Sea basin (Kolodny et al., 2005; Waldmann et al., 2009; Lisker et al., 2010); (12) lake formation at Mudawwara (Petit-Maire et al., 2010); (13) Yammouneh palaeolake (Develle et al., 2011; Gasse et al., 2011, 2015); and (14) Lake Van (Shtokhete et al., 2014; Litt et al., 2014).

Jerusalem caves suggest the interglacial optimum was wet, but low lake levels in the DSB are indicative of drier conditions during the same period.

Whereas these different continental records reflect changes in atmospheric circulation, regional topographic patterns, and/or site-specific climatic and hydrological factors, the lack of detailed, accurately dated long-term records from the northern Levant, especially from different continental archives, limits our understanding of the regional response to climatic conditions during MIS 5. This lack of data restricts the opportunities to resolve the inconsistencies between palaeoclimate records across the region. This study attempts to resolve this by providing a new highresolution record obtained from a speleothem from a cave in the northern Levant. Speleothems are secondary chemical cave deposits, which provide high-resolution proxy tools for palaeoclimate reconstruction (Genty et al., 2001; Drysdale et al., 2007, 2009). Recent studies highlight the significance of speleothem records, in particular for achieving precise chronologies of continental climate changes (Wang et al., 2001; Genty et al., 2003, 2006; Fairchild et al., 2006; Verheyden et al., 2008, 2015; Cheng et al., 2009, 2015). In this paper, we examine the petrography, growth history, and stable isotope geochemistry of a stalagmite from Kanaan Cave, situated close to the Mediterranean coast on the western flank of Mount Lebanon near Beirut, Lebanon. This speleothem provides a precise $\mathrm{U}-\mathrm{Th}$-dated continental record of climate history from the northern Levant spanning the last interglacial and the glacial inception of this region.

\section{Climate and palaeoclimatic setting}

Lebanon is located in the northern Levant between latitudes $33^{\circ} 03^{\prime} \mathrm{N}$ and $34^{\circ} 41^{\prime} \mathrm{N}$ (Fig. 1). The western side of the country is characterized by a Mediterranean climate with an annual precipitation varying between 880 and $1100 \mathrm{~mm}$ along the coastline (Republic of Lebanon, 2003 - Official Report No. 28766-LE). The climate is seasonal, with wet winters (between November and February) and dry, hot summers (from May to October). The present climate is influenced by the Atlantic westerlies, which bring in moist winds associated with extra-tropical cyclones. These originate in the Atlantic and track east across the Mediterranean Sea, forming a series of subsynoptic low-pressure systems. In winter, outbreaks of cold air plunging south over the relatively warm Mediterranean enhance cyclogenesis, creat- 
ing the Cyprus Low (Fig. 1). These low-pressure systems drive moist air onshore, generating intense orographic rainfall across the mountains of the northern Levant. The duration, intensity, and track of these storm systems strongly influence the amount of rainfall in this region.

Conditions during the last interglacial period (LIG) are thought to have been similar to that of today. Marine Isotope Stage 5 is generally known as a period of minimum ice volume between 130 and $75 \mathrm{ka}$ (Emiliani, 1955). The LIG, often defined as being equivalent to MIS 5e (Shackleton et al., 2002), was characterized by a global mean surface temperature less than $2{ }^{\circ} \mathrm{C}$ than present (Otto-Bliesner et al., 2013), caused by the orbital forcing of insolation (Berger and Loutre, 1991). The mean sea level stood 4 to $6 \mathrm{~m}$ higher than present (Kopp et al., 2009), with an important contribution from the Greenland ice sheet (Cuffey and Marshall, 2000). The warmest interval, MIS 5e, was followed by two cold episodes in the ocean (MIS 5d and MIS 5b), alternating with two warmer periods (MIS 5c and MIS 5a).

In the eastern Mediterranean Basin, periods of anoxic conditions associated with the formation of sapropels during MIS 5 are generally related to wet conditions. These horizons are considered to have formed during periods of increased discharge down the River Nile (Rohling et al., 2002, 2015b; Scrivner et al., 2004), linked to enhanced lowlatitude hydrological activity in the Nile headwaters. This peak in rainfall corresponds closely with high summer insolation (Rohling et al., 2002; Moller et al., 2012) and with minima in the precession cycle (Lourens et al., 1996). At that time, the eastern Mediterranean region also experienced enhanced pluvial conditions (Cheddadi and RossignolStrick, 1995; Rossignol-Strick and Paterne, 1999; Kallel et al., 2000). Wet conditions are demonstrated by pollen assemblages found within the sapropel 5 (S5) event from the northeastern Mediterranean Basin (Cheddadi and RossignolStrick, 1995).

Onshore, the climate in the Levant region during MIS 5 has been reconstructed from lacustrine records from interior lake basins such as the Dead Sea and Yammouneh (Kolodny et al., 2005; Gasse et al., 2011, 2015) and speleothem records from central and southern Israel (Frumkin et al., 1999, 2000; Bar-Matthews et al., 1999, 2000, 2003; Ayalon et al., 2013, Vaks et al., 2006, 2010). These archives suggest that climate was generally wet and cold during Termination II $(\sim 140$ $130 \mathrm{ka}$ ). After Termination II, the region experienced an intense warm period coinciding with the development of S5 in the eastern Mediterranean (Rossignol-Strick and Paterne, 1999; Emeis et al., 2003; Rohling et al., 2002; Ziegler et al., 2010). From $\sim 130$ to $120 \mathrm{ka}$, speleothem records from the Peqiin, Soreq, and West Jerusalem caves show periods of rapid growth and decrease in $\delta^{18} \mathrm{O}$ values mainly attributed to higher rainfall, suggesting conditions were wetter than during the early Holocene period (Bar-Matthews et al., 2000, 2003). Corresponding high- $\delta{ }^{13} \mathrm{C}$ records $(\sim 0 \%)$ approaching those of the host carbonate were interpreted as a conse- quence of soil denudation due to high surface runoff in Soreq Cave (Bar-Matthews et al., 2003). However, relatively high $\left(\sim-5 \%\right.$ ) and fluctuating $\delta^{13} \mathrm{C}$ in West Jerusalem Cave suggest extremely dry and unstable conditions during which a C4 vegetation type was introduced in this area (Frumkin et al., 2000). Gasse et al. $(2011,2015)$ suggest wet conditions $(\sim 125-117 \mathrm{ka})$ as shown in the pollen assemblages and oxygen isotopes from the Yammouneh palaeolake, in northern Lebanon. In contrast, the DSB, located to the south (Fig. 1), remained dry during this period (Kolodny et al., 2005). The Samra, Amora, and Lisan lakes, precursors of the Dead Sea, showed lower stands than during the Holocene, even though a slight rise occurred during the last interglacial maximum (Waldmann et al., 2009).

The return to slightly drier conditions, as suggested by an increase in $\delta^{18} \mathrm{O}$ in speleothems from the Soreq and Peqiin caves is dated at $\sim 118-120 \mathrm{ka}$ (Bar-Matthews et al., 2000, 2003). Lower rainfall amounts prevailed until $110 \mathrm{ka}$. But the decrease in $\delta^{13} \mathrm{C}$ in speleothems from these caves (Fig. 1) evidences a reintroduction of a $\mathrm{C} 3$ vegetation cover, indicative of wet conditions (Frumkin et al., 2000). In northern Lebanon the Yammouneh palaeolake records (Develle et al., 2011) located at higher altitude suggest seasonal changes with wet winters, dry summers, and expanded steppe vegetation cover.

From $\sim 110$ to $\sim 100 \mathrm{ka}$, a moderate wet period is suggested by depleted $\delta^{18} \mathrm{O}$ values in speleothems from the Soreq and Peqiin caves and by an increase in arboreal pollen taxa in northern Lebanon (Develle et al., 2011). This coincides with anoxic conditions (sapropel 4, S4) in the eastern Mediterranean (Emeis et al., 2003). Between $\sim 100$ and $\sim 85 \mathrm{ka}$, a return to a slightly drier climate is suggested by speleothem deposition in both the Soreq and Peqiin caves with an increase in $\delta^{18} \mathrm{O}$ values. However, the continued and more stable C3 vegetation cover (Frumkin et al., 2000) in West Jerusalem Cave and the minor lake level increase in the DSB suggest that the climate was probably wetter in the DSB (Waldmann et al., 2009). In northern Lebanon, the high-altitude Yammouneh palaeolake records suggest seasonal variations with steppe vegetation cover similar to the MIS $5 \mathrm{~d}$ period.

From $\sim 85.0$ to $\sim 75.0 \mathrm{ka}$, the last wet and warm phase of MIS 5 occurred in the Levant, corresponding with the sapropel 3 (S3) event in the eastern Mediterranean. In the Soreq, Peqiin (Bar-Matthews et al., 1999, 2003), and Ma'aele Effrayim caves (Vaks et al., 2003, 2006), depleted speleothem $\delta^{18} \mathrm{O}$ values suggest a moderate wet period at this time in agreement with the increase in arboreal pollen taxa in the Yammouneh lacustrine record (Develle et al., 2011). However, the level of Lake Samra in the DSB decreased significantly (Waldmann et al., 2009) and little speleothem deposition occurred in caves situated in the Negev Desert (Fig. 1) after MIS 5c (Vaks et al., 2006, 2010), both suggesting a drier climate during MIS 5a in the south of the region.

It is clear that there are significant discrepancies between the climatic records between the northern (Lebanon, northern 
Syria, and southeastern Turkey) and southern Levant (Jordan, Israel/Palestine), possibly driven by a strong north-south palaeoclimatic gradient that varied dramatically in amplitude over short distances and different climatic trends (wet/dry) especially during MIS 5e. In the northern Levant, few records span the MIS 5 period (Gasse et al., 2011, 2015; Develle et al., 2011). New well-dated speleothem records are needed from this area to decipher if and when the climatic changes that are well recorded in the southern Levant (DSB and the Soreq and Peqiin caves on the Judean Plateau) also affected the northern Levant (Yammouneh, western Mount Lebanon). What is still unclear is how the entire region has responded to the North Atlantic/Mediterranean system versus the southern influences linked to the monsoon system (Arz et al., 2003; Waldmann et al., 2009; Vaks et al., 2010). The K1-2010 speleothem from Kanaan Cave, Lebanon, partly fills the disparity in spatial data coverage in the Levant, and may help understand the spatial climate heterogeneity, if any, of the palaeoclimatic patterns.

\section{Location of Kanaan Cave}

Kanaan Cave is located on the western flank of central Mount Lebanon, $15 \mathrm{~km}$ northeast of Beirut at $33^{\circ} 54^{\prime} 25 \mathrm{~N}$, $35^{\circ} 36^{\prime} 25 \mathrm{E}$. The cave developed in the Middle Jurassic Kesrouane Formation, a thick predominantly micritic limestone and dolomite sequence with an average stratigraphic thickness of $1000 \mathrm{~m}$ (Fig. 2a). Being located only $2.5 \mathrm{~km}$ from the Mediterranean coast and at just $98 \mathrm{~m}$ above sea level (a.s.l.), the cave is strongly influenced by the maritime Mediterranean climate.

Kanaan Cave is a $162 \mathrm{~m}$ long relict conduit discovered during quarrying in 1997. A $23 \mathrm{~cm}$ long stalagmite, sample K12010 was collected from the top of a fallen limestone block in the central part of the Collapse I chamber, approximately $20 \mathrm{~m}$ from the (formerly closed) cave entrance (Fig. 2b-c). The fallen block rests on an unknown thickness of sediment. The passage height at this location is $2.4 \mathrm{~m}$ with approximately $50 \mathrm{~m}$ of limestone overburden. Presently, the stalagmite receives no dripping water, although some drip water occurs in other parts of the Collapse I chamber during winter and spring seasons. The cave is generally dry during the summer months. The air temperature in Collapse I chamber is $20^{\circ} \mathrm{C} \pm 1{ }^{\circ} \mathrm{C}$.

\section{Methods}

The stalagmite (sample K1-2010) was cut along its growth axis after retrieval from the cave, and polished using 120 $4000 \mu \mathrm{m}$ silicon carbide (SiC) paper. Petrographic observations were performed with an optical binocular microscope.

The first $10 \mathrm{U}$-series datings were carried out at the NERC Isotope Geosciences Laboratory (NIGL), British Geological Survey, Keyworth, UK. Seven new ages were recently com- pleted by the NIGL geochemistry laboratory and the Geochemistry Laboratory, Earth Science Department, University of Melbourne, Australia. Powdered 100 to $400 \mathrm{mg}$ calcite samples were collected with a dental drill from $11 \mathrm{lev}$ els along the growth axis of the speleothem, taking care to sample along growth horizons. Chemical separation and purification of uranium and thorium were performed following the procedures of Edwards et al. (1987) with modifications. Data were obtained on a Thermo Neptune Plus multicollector inductively coupled plasma mass spectrometer (MCICP-MS) following procedures modified from Anderson et al. (2008), Heiss et al. (2012), and Hellstrom (2006). Mass bias and SEM gain for Th measurements were corrected using an in-house ${ }^{229} \mathrm{Th}-{ }^{230} \mathrm{Th}-{ }^{232} \mathrm{Th}$ reference solution calibrated against CRM 112a. Quoted uncertainties for activity ratios, initial ${ }^{234} \mathrm{U} /{ }^{238} \mathrm{U}$, and ages include a ca. $0.2 \%$ uncertainty calculated from the combined ${ }^{236} \mathrm{U} /{ }^{229} \mathrm{Th}$ tracer calibration uncertainty and measurement reproducibility of reference materials (HU-1, CRM 112a, in-house Th reference solution) as well as the measured isotope ratio uncertainty. Ages are calculated from time of analysis (2014) and also in years before 1950 with an uncertainty at the $2 \sigma$ level, typically of between 500 and 1000 years (see Table 1).

Samples for $\delta^{13} \mathrm{C}$ and $\delta^{18} \mathrm{O}$ measurements were drilled along the speleothem central axis using a $1 \mathrm{~mm}$ dental drill. Ethanol was used to clean the speleothem surface and drill bit prior to sampling. Sample resolution was 1 to $1.2 \mathrm{~mm}$. A total of 206 samples were analysed using the Nu Carb carbonate device coupled to a $\mathrm{Nu}$ Perspective MS at the Vrije Universiteit Brussel with analytical uncertainties less than $0.1 \%(2 \mathrm{~s})$ for oxygen and $0.05 \%$ ( $2 \mathrm{~s})$ for carbon. Isotopic equilibrium analyses were carried out using six recent calcite samples collected in the cave and Hendy tests (Hendy, 1971) were carried out at five different locations along the speleothem growth axis. No evidence for severe out-of-equilibrium deposition was detected along the growth axis of the stalagmite.

Three seepage water samples and three water pool samples from Kanaan Cave were collected for $\delta^{18} \mathrm{O}$ measurements in hermetically sealed glass bottles. Measurements were performed at the Vrije Universiteit Brussel on a Picarro L2130$i$ analyser using the cavity ring-down spectroscopy (CRDS) technique (Van Geldern and Barth Johannes, 2012). All values are reported in per mill $(\%)$ relative to Vienna Standard Mean Ocean Water (V-SMOW2). Analytical uncertainties $(2 \sigma)$ were less than $0.10 \%$.

\section{Results}

\subsection{Petrography}

The speleothem collected from Kanaan Cave is $23 \mathrm{~cm}$ long and up to $10 \mathrm{~cm}$ wide (Fig. 2). In section it displays regular layers of dense calcite ranging in colour from dark brown to light yellow with a regular thin $(<0.2 \mathrm{~mm})$ lamination 

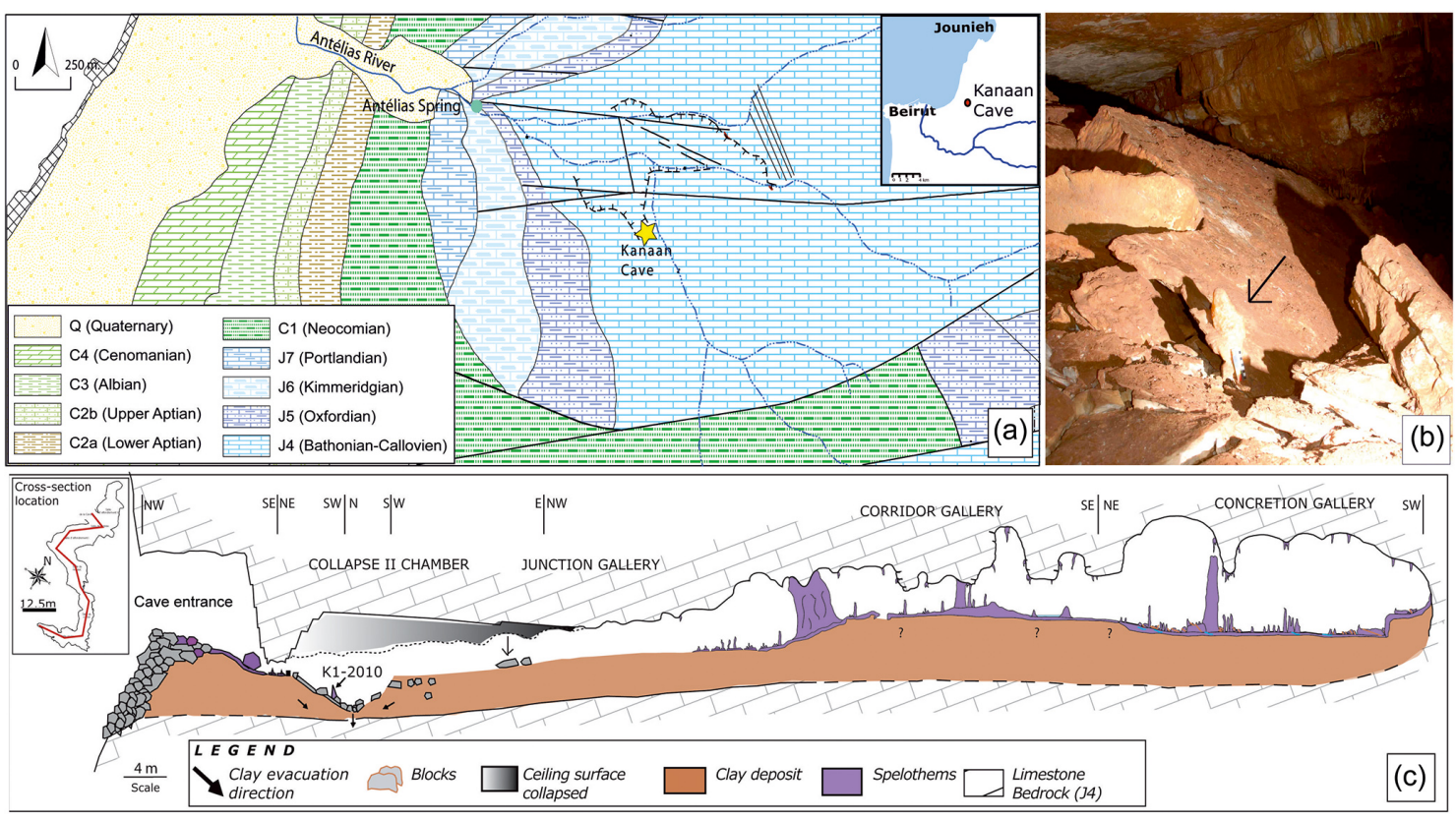

Figure 2. (a) Location map of Kanaan Cave and the continental records in the Levant. (a) Geological map of the Antelias region (western flank of central Mount Lebanon; Dubertret, 1955). (b) Photo of K1-2010 stalagmite in the Collapse Chamber. (c) Geomorphological section of Kanaan Cave showing the location of the stalagmite K1-2010 (Nehme, 2013).

Table 1. U-Th results of K1-2010 dating.

\begin{tabular}{|c|c|c|c|c|c|c|c|c|c|c|c|}
\hline Sample number & $\begin{array}{r}\text { Distance from } \\
\text { top }(\mathrm{cm})\end{array}$ & $\begin{array}{r}\mathrm{U} \\
(\mathrm{ppm})\end{array}$ & $\begin{array}{r}{ }^{232} \mathrm{Th} \\
(\mathrm{ppb})\end{array}$ & $\begin{array}{r}{\left[{ }^{230} \mathrm{Th} /{ }^{232} \mathrm{Th}\right]} \\
\text { (measured) }\end{array}$ & $\begin{array}{r}\left.{ }^{230} \mathrm{Th} /{ }^{238} \mathrm{U}\right] \\
(\text { corrected })\end{array}$ & $\begin{array}{r}{\left[{ }^{234} \mathrm{U} /{ }^{238} \mathrm{U}\right]} \\
\text { (corrected) }\end{array}$ & $\rho_{08-48}$ & $\begin{array}{r}\text { Age } \\
\text { uncorrected (ka) }\end{array}$ & $\begin{array}{r}\text { Age } \\
\text { corrected (ka) }\end{array}$ & $\begin{array}{r}\text { Age } \mathrm{BP}_{1950} \\
\text { corrected (ka) }\end{array}$ & {$\left[{ }^{234} \mathrm{U}^{238} \mathrm{U}\right]_{\text {initial }}$} \\
\hline KA STM 1-3 & 10.0 & 0.05971 & 0.7545 & 108.5 & $\begin{array}{r}\mathbf{0 . 4 4 8 6} \pm \mathbf{0 . 5 6} \\
0.4463 \pm 0.93\end{array}$ & $\begin{array}{r}\mathbf{0 . 8 4 3 9} \pm \mathbf{0 . 3 3} \\
0.8433 \pm 0.47\end{array}$ & $\begin{array}{l}\mathbf{0 . 2 7} \\
0.58\end{array}$ & $85.83 \pm 0.70$ & $\begin{array}{l}\mathbf{8 5 . 3 6} \pm \mathbf{0 . 7 8} \\
84.81 \pm 1.01\end{array}$ & $\begin{array}{l}\mathbf{8 5 . 3 0} \pm \mathbf{0 . 7 8} \\
84.75 \pm 1.01\end{array}$ & $\begin{array}{l}\mathbf{0 . 8 0 1 4} \pm \mathbf{0 . 5 0} \\
0.8009 \pm 0.62\end{array}$ \\
\hline$\underset{*}{\text { KA STM 1-18 }}$ & 31.0 & 0.04279 & 0.5226 & 112.1 & $\begin{aligned} \mathbf{0 . 4 5 4 6} & \pm \mathbf{0 . 6 2} \\
0.4524 & \pm 0.95\end{aligned}$ & $\begin{array}{r}\mathbf{0 . 8 4 7 8} \pm \mathbf{0 . 2 9} \\
0.8471 \pm 0.43\end{array}$ & $\begin{array}{l}\mathbf{0 . 2 7} \\
0.58\end{array}$ & $86.92 \pm 0.79$ & $\begin{array}{l}\mathbf{8 6 . 4 6} \pm \mathbf{0 . 8 5} \\
85.93 \pm 1.05\end{array}$ & $\begin{array}{l}\mathbf{8 6 . 4 0} \pm \mathbf{0 . 8 5} \\
85.86 \pm 1.05\end{array}$ & $\begin{array}{l}\mathbf{0 . 8 0 5 7} \pm \mathbf{0 . 4 1} \\
0.8052 \pm 0.58\end{array}$ \\
\hline$\underset{*}{\text { KA STM 1-12 }}$ & 42.0 & 0.04502 & 0.1626 & 367.1 & $\begin{array}{r}\mathbf{0 . 4 3 5 2} \pm \mathbf{0 . 3 4} \\
0.4345 \pm 0.41\end{array}$ & $\begin{array}{l}\mathbf{0 . 8 4 7 8} \pm \mathbf{0 . 1 5} \\
0.8476 \pm 0.18\end{array}$ & $\begin{array}{l}\mathbf{0 . 0 8} \\
0.28\end{array}$ & $80.94 \pm 0.45$ & $\begin{array}{l}\mathbf{8 0 . 8 1} \pm \mathbf{0 . 4 6} \\
80.65 \pm 0.49\end{array}$ & $\begin{array}{l}\mathbf{8 0 . 7 4} \pm \mathbf{0 . 4 6} \\
80.59 \pm 0.49\end{array}$ & $\begin{array}{l}\mathbf{0 . 8 0 8 8} \pm \mathbf{0 . 2 5} \\
0.8087 \pm 0.25\end{array}$ \\
\hline$\underset{*}{\text { KA STM 1-11 }}$ & 58.0 & 0.07340 & 0.2089 & 516.7 & $\begin{array}{l}\mathbf{0 . 4 8 2 9} \pm \mathbf{0 . 3 0} \\
0.4824 \pm 0.34\end{array}$ & $\begin{array}{r}\mathbf{0 . 8 5 3 2} \pm \mathbf{0 . 1 3} \\
0.8530 \pm 0.15\end{array}$ & $\begin{array}{l}\mathbf{0 . 0 6} \\
0.22\end{array}$ & $94.27 \pm 0.50$ & $\begin{array}{l}\mathbf{9 4 . 2 1} \pm \mathbf{0 . 5 1} \\
94.04 \pm 0.53\end{array}$ & $\begin{array}{l}\mathbf{9 4 . 1 5} \pm \mathbf{0 . 5 1} \\
93.98 \pm 0.53\end{array}$ & $\begin{array}{l}\mathbf{0 . 8 0 8 5} \pm \mathbf{0 . 2 0} \\
0.8083 \pm 0.25\end{array}$ \\
\hline $\begin{array}{l}\text { KA STM 1-17 } \\
*\end{array}$ & 69.0 & 0.05857 & 0.3388 & 252.3 & $\begin{array}{l}\mathbf{0 . 4 8 6 8} \pm \mathbf{0 . 4 9} \\
0.4859 \pm 0.58\end{array}$ & $\begin{array}{l}\mathbf{0 . 8 5 0 0} \pm \mathbf{0 . 2 3} \\
0.8497 \pm 0.28\end{array}$ & $\begin{array}{l}\mathbf{0 . 0 9} \\
0.30\end{array}$ & $96.33 \pm 0.85$ & $\begin{array}{l}\mathbf{9 6 . 1 1} \pm \mathbf{0 . 8 6} \\
95.85 \pm 0.91\end{array}$ & $\begin{array}{l}\mathbf{9 6 . 0 4} \pm \mathbf{0 . 8 6} \\
95.79 \pm 0.91\end{array}$ & $\begin{array}{l}\mathbf{0 . 8 0 4 2} \pm \mathbf{0 . 3 5} \\
0.8031 \pm 0.40\end{array}$ \\
\hline$\underset{*}{\text { KA STM 1-10 }}$ & 89.0 & 0.05592 & 0.7053 & 121.9 & $\begin{array}{r}\mathbf{0 . 5 0 3 7} \pm \mathbf{0 . 4 5} \\
0.5017 \pm 0.78\end{array}$ & $\begin{array}{r}\mathbf{0 . 8 5 7 9} \pm \mathbf{0 . 2 1} \\
0.8573 \pm 0.37\end{array}$ & $\begin{array}{l}\mathbf{0 . 4 4} \\
0.72\end{array}$ & $100.41 \pm 0.61$ & $\begin{array}{l}\mathbf{9 9 . 9 4} \pm \mathbf{0 . 6 9} \\
99.40 \pm 0.94\end{array}$ & $\begin{array}{l}\mathbf{9 9 . 8 8} \pm \mathbf{0 . 6 9} \\
99.34 \pm 0.94\end{array}$ & $\begin{array}{l}\mathbf{0 . 8 1 1 6} \pm \mathbf{0 . 2 5} \\
0.8111 \pm 0.49\end{array}$ \\
\hline KA STM 1-2 & 114.0 & 0.06580 & 0.8400 & 124.6 & $\begin{array}{c}\mathbf{0 . 5 2 0 8} \pm \mathbf{0 . 5 1} \\
0.5188 \pm 0.80\end{array}$ & $\begin{array}{r}\mathbf{0 . 8 7 1 6} \pm \mathbf{0 . 3 1} \\
0.8710 \pm 0.43\end{array}$ & $\begin{array}{l}\mathbf{0 . 2 6} \\
0.58\end{array}$ & $103.03 \pm 0.90$ & $\begin{array}{l}\mathbf{1 0 2 . 5 7} \pm \mathbf{0 . 9 6} \\
102.03 \pm 1.14\end{array}$ & $\begin{aligned} \mathbf{1 0 2 . 5 0} & \pm \mathbf{0 . 9 6} \\
101.97 & \pm 1.14\end{aligned}$ & $\begin{array}{l}\mathbf{0 . 8 2 8 4} \pm \mathbf{0 . 4 8} \\
0.8279 \pm 0.60\end{array}$ \\
\hline KA STM 1-9 & 129.0 & 0.07067 & 0.8548 & 139.8 & $\begin{array}{r}\mathbf{0 . 5 5 4 1} \pm \mathbf{0 . 4 0} \\
0.5523 \pm 0.67\end{array}$ & $\begin{aligned} \mathbf{0 . 8 8 0 9} & \pm \mathbf{0 . 1 9} \\
0.8804 & \pm 0.34\end{aligned}$ & $\begin{array}{l}\mathbf{0 . 4 2} \\
0.72\end{array}$ & $112.31 \pm 0.68$ & $\begin{array}{r}\mathbf{1 1 1 . 8 8} \pm \mathbf{0 . 7 4} \\
111.37 \pm 0.95\end{array}$ & $\begin{aligned} \mathbf{1 1 1 . 8 1} & \pm \mathbf{0 . 7 4} \\
111.31 & \pm 0.95\end{aligned}$ & $\begin{array}{r}\mathbf{0 . 8 3 6 7} \pm \mathbf{0 . 2 4} \\
0.8363 \pm 0.48\end{array}$ \\
\hline KA STM 1-8 & 140.0 & 0.05426 & 2.676 & 35.1 & $\begin{array}{r}\mathbf{0 . 5 6 2 3} \pm \mathbf{1 . 1} \\
0.5551 \pm 2.47\end{array}$ & $\begin{array}{l}\mathbf{0 . 8 6 4 0} \pm \mathbf{0 . 5 9} \\
0.8616 \pm 1.32\end{array}$ & $\begin{array}{l}\mathbf{0 . 8 2} \\
0.86\end{array}$ & $121.74 \pm 0.82$ & $\begin{array}{r}\mathbf{1 1 9 . 9 1} \pm \mathbf{1 . 5 3} \\
117.75 \pm 2.98\end{array}$ & $\begin{aligned} \mathbf{1 1 9 . 8 4} & \pm \mathbf{1 . 5 3} \\
117.68 & \pm 2.98\end{aligned}$ & $\begin{array}{l}\mathbf{0 . 8 0 9 2} \pm \mathbf{0 . 8 7} \\
0.8071 \pm 1.86\end{array}$ \\
\hline KA STM 1-7 & 158.0 & 0.05155 & 1.207 & 74.1 & $\begin{array}{l}\mathbf{0 . 5 6 7 1} \pm \mathbf{0 . 5 9} \\
0.5638 \pm 1.16\end{array}$ & $\begin{array}{l}\mathbf{0 . 8 5 5 8} \pm \mathbf{0 . 3 1} \\
0.8546 \pm 0.63\end{array}$ & $\begin{array}{l}\mathbf{0 . 6 7} \\
0.84\end{array}$ & $125.46 \pm 0.89$ & $\begin{array}{l}\mathbf{1 2 4 . 5 7} \pm \mathbf{1 . 0 8} \\
123.54 \pm 1.62\end{array}$ & $\begin{aligned} \mathbf{1 2 4 . 5 1} & \pm \mathbf{1 . 0 8} \\
123.48 & \pm 1.62\end{aligned}$ & $\begin{aligned} \mathbf{0 . 7 9 5 0} & \pm \mathbf{0 . 5 0} \\
0.7940 & \pm 0.88\end{aligned}$ \\
\hline $\begin{array}{l}\text { KA STM 1-16 } \\
*\end{array}$ & 159.0 & 0.04663 & 0.8603 & 96.9 & $\begin{array}{r}\mathbf{0 . 5 9 7 8} \pm \mathbf{0 . 6 8} \\
0.5953 \pm 1.01\end{array}$ & $\begin{array}{r}\mathbf{0 . 8 6 0 2} \pm \mathbf{0 . 3 3} \\
0.8593 \pm 0.54\end{array}$ & $\begin{array}{l}\mathbf{0 . 3 1} \\
0.65\end{array}$ & $137.62 \pm 1.91$ & $\begin{aligned} \mathbf{1 3 6 . 9 1} & \pm \mathbf{1 . 9 4} \\
136.08 & \pm 2.18\end{aligned}$ & $\begin{aligned} \mathbf{1 3 6 . 8 5} & \pm \mathbf{1 . 9 4} \\
136.02 & \pm 2.18\end{aligned}$ & $\begin{array}{l}\mathbf{0 . 7 9 4 2} \pm \mathbf{0 . 5 9} \\
0.7934 \pm 0.86\end{array}$ \\
\hline KA STM 1-6 & 167.0 & 0.07508 & 3.488 & 37.5 & $\begin{array}{r}\mathbf{0 . 5 6 6 5} \pm \mathbf{1 . 0} \\
0.5598 \pm 2.27\end{array}$ & $\begin{array}{r}\mathbf{0 . 8 2 9 8} \\
0.8270 \pm 1.26\end{array}$ & $\begin{array}{l}\mathbf{0 . 8 5} \\
0.90\end{array}$ & $135.85 \pm 0.97$ & $\begin{array}{l}\mathbf{1 3 3 . 9 9} \pm \mathbf{1 . 6 3} \\
131.80 \pm 3.06\end{array}$ & $\begin{aligned} \mathbf{1 3 3 . 9 3} & \pm \mathbf{1 . 6 3} \\
131.74 & \pm 3.06\end{aligned}$ & $\begin{array}{l}\mathbf{0 . 7 5 1 5} \pm \mathbf{0 . 9 3} \\
0.7491 \pm 1.87\end{array}$ \\
\hline$\underset{*}{\text { KA STM 1-15 }}$ & 169.0 & 0.1179 & 0.3388 & 555.5 & $\begin{array}{r}\mathbf{0 . 5 5 2 5} \pm \mathbf{0 . 3 0} \\
0.5521 \pm 0.33\end{array}$ & $\begin{array}{r}\mathbf{0 . 8 3 1 9} \pm \mathbf{0 . 1 7} \\
0.8317 \pm 0.19\end{array}$ & $\begin{array}{l}\mathbf{0 . 0 4} \\
0.17\end{array}$ & $126.63 \pm 0.90$ & $\begin{array}{l}\mathbf{1 2 6 . 5 1} \pm \mathbf{0 . 9 0} \\
126.37 \pm 0.92\end{array}$ & $\begin{aligned} \mathbf{1 2 6 . 4 4} & \pm \mathbf{0 . 9 0} \\
126.31 & \pm 0.92\end{aligned}$ & $\begin{array}{l}\mathbf{0 . 7 5 9 8} \pm \mathbf{0 . 3 2} \\
0.7596 \pm 0.36\end{array}$ \\
\hline KA STM 1-5 & 174.0 & 0.1425 & 1.623 & 147.2 & $\begin{aligned} \mathbf{0 . 5 4 9 7} & \pm \mathbf{0 . 3 7} \\
0.5480 & \pm 0.62\end{aligned}$ & $\begin{aligned} \mathbf{0 . 8 2 9 7} & \pm \mathbf{0 . 1 8} \\
0.8291 & \pm 0.33\end{aligned}$ & $\begin{array}{l}\mathbf{0 . 4 7} \\
0.76\end{array}$ & $126.47 \pm 0.77$ & $\begin{aligned} \mathbf{1 2 6 . 0 2} & \pm \mathbf{0 . 8 3} \\
125.50 & \pm 1.03\end{aligned}$ & $\begin{aligned} \mathbf{1 2 5 . 9 6} & \pm \mathbf{0 . 8 3} \\
125.44 & \pm 1.03\end{aligned}$ & $\begin{array}{r}\mathbf{0 . 7 5 7 0} \pm \mathbf{0 . 2 6} \\
0.7564 \pm 0.53\end{array}$ \\
\hline KA STM 1-4 & 180.0 & 0.1549 & 0.5079 & 520.1 & $\begin{array}{l}\mathbf{0 . 5 6 0 2} \\
0.5598 \pm 0.27\end{array}$ & $\begin{array}{r}\mathbf{0 . 8 3 2 8} \pm \mathbf{0 . 1 3} \\
0.8326 \pm 0.15\end{array}$ & $\begin{array}{l}\mathbf{0 . 0 6} \\
0.27\end{array}$ & $129.92 \pm 0.80$ & $\begin{array}{r}\mathbf{1 2 9 . 7 9} \pm \mathbf{0 . 8 0} \\
129.64 \pm 0.82\end{array}$ & $\begin{array}{r}\mathbf{1 2 9 . 7 2} \pm \mathbf{0 . 8 0} \\
129.57 \pm 0.82\end{array}$ & $\begin{array}{l}\mathbf{0 . 7 5 8 8} \pm \mathbf{0 . 2 6} \\
0.7586 \pm 0.26\end{array}$ \\
\hline$\underset{*}{\text { KA STM 1-14 }}$ & 192.0 & 0.1144 & 0.5855 & 321.1 & $\begin{array}{r}\mathbf{0 . 5 5 2 0} \pm \mathbf{0 . 3 5} \\
0.5512 \pm 0.42\end{array}$ & $\begin{array}{r}\mathbf{0 . 8 2 9 8} \\
0.8295 \pm 0.18\end{array}$ & $\begin{array}{l}\mathbf{0 . 1 0} \\
0.34\end{array}$ & $127.26 \pm 1.01$ & $\begin{aligned} \mathbf{1 2 7 . 0 5} & \pm \mathbf{1 . 0 1} \\
126.81 & \pm 1.05\end{aligned}$ & $\begin{aligned} \mathbf{1 2 6 . 9 9} & \pm \mathbf{1 . 0 1} \\
126.74 & \pm 1.05\end{aligned}$ & $\begin{array}{l}\mathbf{0 . 7 5 6 4} \pm \mathbf{0 . 3 4} \\
0.7561 \pm 0.38\end{array}$ \\
\hline UMD120325-206 & $\underline{199.0}$ & $\underline{0.0630}$ & $\underline{0.1006}$ & $\underline{1058.1}$ & $\underline{0.5440} \pm 0.20$ & $\underline{0.8188} \pm 23$ & & $\underline{127.43 \pm 1.28}$ & $\frac{\mathbf{1 2 7 . 3 6} \pm \mathbf{1 . 2 7}}{127.28 \pm 1.30}$ & $\frac{\mathbf{1 2 7 . 3 0} \pm \mathbf{1 . 2 7}}{127.22 \pm 1.30}$ & $\frac{\mathbf{0 . 7 4 0 4} \pm \mathbf{0 . 3 9}}{0.7405 \pm 0.40}$ \\
\hline $\begin{array}{l}\text { KA STM 1-13 } \\
*\end{array}$ & 206.0 & 0.1241 & 8.566 & 34.6 & $\begin{array}{r}\mathbf{0 . 7 8 3 7} \pm \mathbf{0 . 9 0} \\
0.7787 \pm 1.97\end{array}$ & $\begin{array}{r}\mathbf{0 . 9 1 7 7} \pm \mathbf{0 . 5 8} \\
0.9157 \pm 1.3\end{array}$ & $\begin{array}{l}\mathbf{0 . 8 9} \\
0.96\end{array}$ & $228.61 \pm 2.90$ & $\begin{aligned} \mathbf{2 2 6 . 1 4} & \pm \mathbf{3 . 2 8} \\
223.21 & \pm 4.78\end{aligned}$ & $\begin{aligned} \mathbf{2 2 6 . 0 8} & \pm \mathbf{3 . 2 8} \\
223.15 & \pm 4.78\end{aligned}$ & $\begin{array}{l}\mathbf{0 . 8 4 4 2} \pm \mathbf{1 . 1 8} \\
0.8418 \pm 0.26\end{array}$ \\
\hline
\end{tabular}

Data in bold calculated using average continental detritus $\mathrm{U}-\mathrm{Th}$ composition: $\left({ }^{230} \mathrm{Th} /{ }^{238} \mathrm{U}\right)=1.0 \pm 50 \%,\left({ }^{232} \mathrm{Th} /{ }^{238} \mathrm{U}\right)=1.2 \pm 50 \%,{ }^{234} \mathrm{U} /$
$\left({ }^{230} \mathrm{Th} /{ }^{238} \mathrm{U}\right)=0.9732 \pm 50 \%,\left({ }^{232} \mathrm{Th} /{ }^{238} \mathrm{U}\right)=0.5407 \pm 50 \%,\left({ }^{234} \mathrm{U} /{ }^{238} \mathrm{U}\right)=1 \pm 50 \%$. Underlined data are uncorrected activity ratios. 
in places. The speleothem has two clearly defined growth phases, characterized by an abrupt hiatus where the stalagmite was tilted around $45^{\circ}$ and then recommenced growing.

The lower segment (Segment 1) is $8.2 \mathrm{~cm}$ long and $8.5 \mathrm{~cm}$ wide (Fig. 3) and displays a general growth axis tilted at a $45^{\circ}$ angle (clockwise) relative to upper segment. The regular deposition of translucent columnar crystals is interrupted by clayey layers (discontinuities) mostly at $17 \mathrm{~cm}$, from 15.6 to $15.2 \mathrm{~cm}$, and at $14.2 \mathrm{~cm}$. Between 12.2 and $14.2 \mathrm{~cm}$, the lamina in the central axial part of the speleothem show continuous clear and translucent layering, but which becomes increasingly clayey towards the outer edge of the sample. The higher segment (Segment 2) is $12.3 \mathrm{~cm}$ long and $4-6 \mathrm{~cm}$ wide. At the base, the general growth axis is tilted at $16^{\circ}$ (anticlockwise) to the azimuth axis, gradually becoming more vertical towards the top. The general structure of this section is characterized by uniform yellow translucent columnar crystals interrupted by marked opaque yellow layers, at 9,8 , $5.6,3.2$, and $2.8 \mathrm{~cm}$ depth (from the top of the stalagmite).

\subsection{Uranium series (U-Th) dating}

A rectified age model is proposed here based on the new ages recently completed: the stalagmite grew from $127.2 \pm 1.3$ $(2 \sigma)$ to $85.4 \pm 0.8 \mathrm{ka}(2 \sigma)$. An extrapolated age of $83.1 \mathrm{ka}$ for the top of the stalagmite was calculated from the agedepth model in Fig. 4 obtained using the P_Sequence function of the OxCal geochronology application, which is based on Bayesian statistics (Bronk Ramsey, 2008). All ages in Table 1 are calculated with two different possible detrital U-Th compositions, as no data from Kanaan Cave are presently available to better constrain the corrections. The first correction is the typical continental detritus composition as used by Verheyden et al. (2008) and the second is that used determined by Kauffman et al. (1998) for the Soreq caves which might better reflect the prevalent detritus composition in a carbonate-dominated terrain.

Basically the age uncertainties and ${ }^{230} \mathrm{Th} /{ }^{232} \mathrm{Th}$ activity ratios in the data set are such that both options (i.e. Soreq Cave vs. average continental detritus) result in statistically equivalent dates (i.e. Sample 10: $99.94 \pm 0.69$ ka calculated with the average continental detritus and $99.40 \pm 0.94 \mathrm{ka}$ calculated using Soreq Cave detritus).

The greater number of disturbed ages in the lower segment of the stalagmite, which has comparatively high initial thorium concentrations $\left({ }^{230} \mathrm{Th} /{ }^{232} \mathrm{Th}\right.$ activity ratios as low as 34), is most likely due to contamination of the U-Th subsamples with organic material, or iron oxides from mud layers that are common in this part of the record. The basal age of $223.2 \pm 4.8$ is clearly out of sequence probably due to accidental inclusion of host rock in the analysed sample. Consequently, the oldest valid U-Th date is $127.2 \pm 1.3 \mathrm{ka}$ from a sample located $7 \mathrm{~mm}$ above the base of the stalagmite, and extrapolation of the age model places the beginning of growth at $\sim 128.8 \mathrm{ka}$. However, as no other coeval stalag- mites from Kanaan Cave have yet been dated, it is unclear whether the base of our record corresponds to the onset of the LIG optimum. In general, U-Th dates from the upper segment of the stalagmite were more consistent with only one out of seven dates $(80.6 \pm 0.5 \mathrm{ka})$ clearly out of sequence.

Following the exclusion of obvious outliers, the remaining U-Th data set showed a number of age reversals. For the purposes of age-depth modelling, where age reversals were resolvable at the $3 \sigma$ level, the younger date was assumed to represent the correct age progression and the older dates were excluded such as the basal age in the previous age model (Verheyden et al., 2015). Age models obtained using linear interpolation, and the OxCal package were statistically equivalent at the $95 \%$ confidence level, with the latter chosen as the basis for stable isotope proxy data interpretation, owing to its more robust treatment of uncertainty propagation.

\subsection{Modern cave water and calcite isotopic compositions}

Recent cave water (a proxy for rainfall $\delta^{18} \mathrm{O}$ ) sampled from the cave shows an average $\delta^{18} \mathrm{O}$ value of $-5.43 \pm 0.06 \%$. $\delta^{18} \mathrm{O}$ and $\delta \mathrm{D}$ seepage water values in Kanaan Cave falls on the Lebanese meteoric waterline (Saad et al., 2000) indicating that no severe evaporation processes occur in the epikarst before precipitating the speleothem (see Supplement). Recent calcite analyses in the cave (soda straw, recent calcite deposition) display an average $\delta^{13} \mathrm{C}$ value of $-11.6 \%$ o \pm 0.4 and $\delta^{18} \mathrm{O}$ value of $-4.9 \% \circ \pm 0.7$ (see Supplement). The average $\delta^{18} \mathrm{O}$ value for the recent calcite is close to the theoretical calcite precipitation value of $-4.4 \% \circ\left(20^{\circ} \mathrm{C}\right)$ - present temperature in the cave - using the Kim and O’Neil (1997) equilibrium equation.

\subsection{Oxygen and carbon isotope series}

If precipitation occurs at isotopic equilibrium, the calcite $\delta^{18} \mathrm{O}$ should not show any significant enrichment along a single lamina away from the growth axis and no covariation between $\delta^{18} \mathrm{O}$ and $\delta^{13} \mathrm{C}$ should occur. As indicated by several of these so-called Hendy tests (Hendy, 1971) performed along growth layers, no severe out-of-equilibrium processes during precipitation of the calcite seem to have occurred (see Supplement).

The $\delta^{18} \mathrm{O}$ values from K1-2010 (Fig. 4) ranged from -3.5 to $-7.8 \%$, with an overall mean of $-5.1 \%$. Lower values $(\sim-7.5 \%)$ are observed at the basal part of the stalagmite. Values enrichment begin at $\sim 126 \mathrm{ka}$ and increase rapidly to $\sim-4.45 \%$ o until $\sim 120 \mathrm{ka}$. High $\delta^{18} \mathrm{O}$ values (generally between -4.4 and $-4 \%$ o) are observed until the top of the stalagmite at $\sim 84 \mathrm{ka}$, except for two periods with relatively lower $\delta^{18} \mathrm{O}$. From 102.8 to $100.8 \mathrm{ka}$ (interpolated), the $\delta^{18} \mathrm{O}$ values decrease from -4.6 to $-6.18 \%$ o in $\sim 2.0 \mathrm{kyr}$. At $\sim 94 \mathrm{ka}$, a rapid decrease in $\delta^{18} \mathrm{O}$ values leads to a peak of $-5.5 \%$ at $\sim 92.3 \mathrm{ka}$ (interpolated). The top of the stalag- 


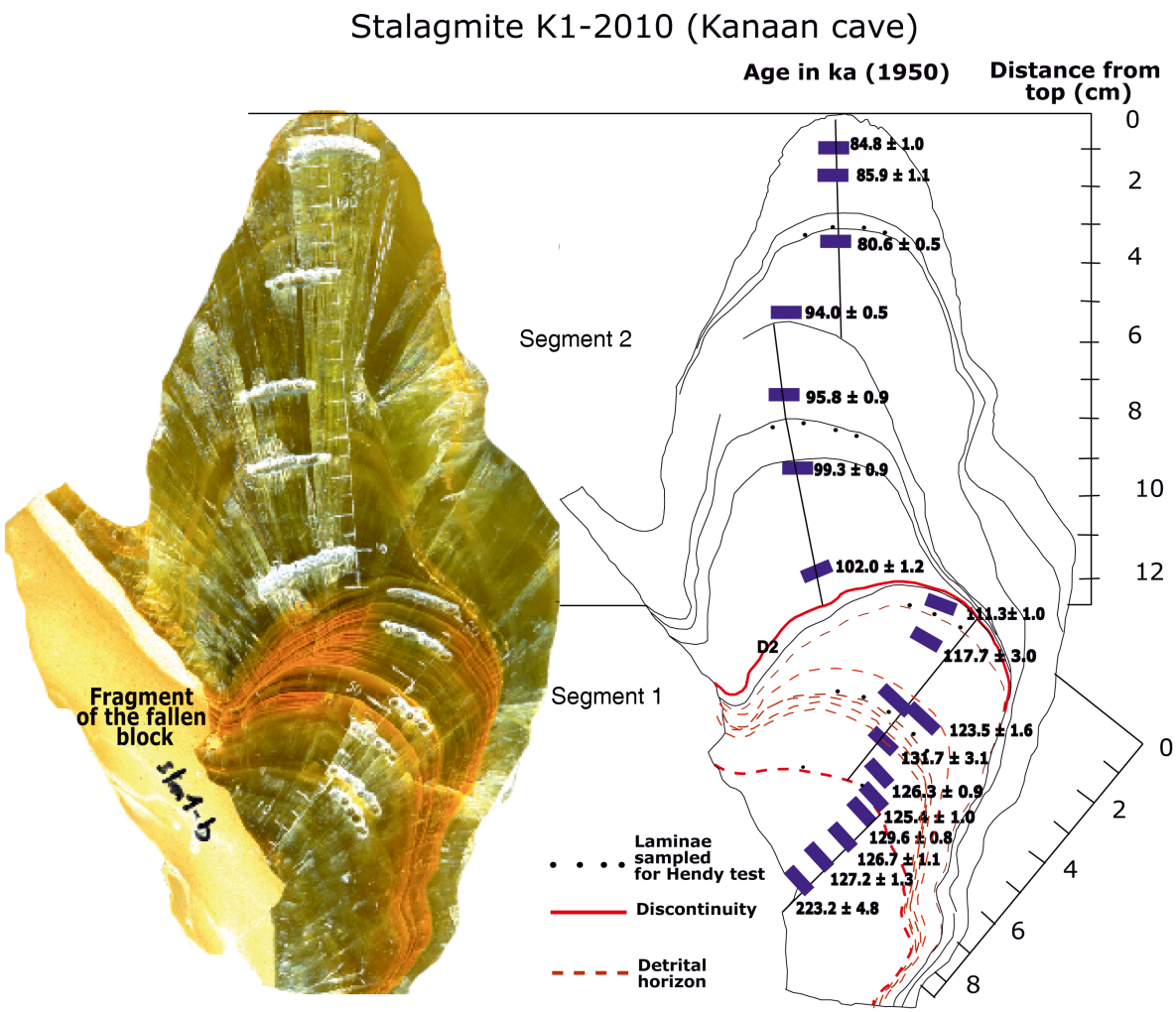

Figure 3. Cut face of the K1-2010 speleothem and sketch showing the position of the uranium series age data. In Segment 1, the dashed line indicates detrital layers and U-Th shows many more uncertainties than those in the Segment 2. The third age from the base of Segment 1 is an outlier. Segment 1 is tilted from its initial position probably due to the suffosion of clay deposits in the Collapse Chamber that caused the block on which the speleothem grew to subside. Red lines indicate discontinuities.

mite at $\sim 84 \mathrm{ka}$ exhibit the highest $\delta^{18} \mathrm{O}$ values of $-3.5 \%$. The $\delta^{13} \mathrm{C}$ VPDB values range between -10.0 and $-12.4 \%$ o with an overall mean of $-11.3 \%$ as shown in Fig. 5. The $\delta^{13} \mathrm{C}$ curve shows relatively minor variations. However, the most depleted values $(-12 \%)$ are observed at the base of the speleothem, from $\sim 129$ to $\sim 125.6 \mathrm{ka}$ (interpolated), followed by a $\delta^{13} \mathrm{C}$ enrichment of $\sim 2 \%$ o from 125.6 (interpolated) to $\sim 122 \mathrm{ka}$ and stays around $-11 \%$ o between $\sim 120$ and $\sim 110 \mathrm{ka}$. After $\sim 110 \mathrm{ka}$, generally lower $\delta^{13} \mathrm{C}$ values prevail with a surprising stable period between $\sim 103$ and $\sim 91 \mathrm{ka}$. From $\sim 91$ to $\sim 87 \mathrm{ka}$, a $1.1 \%$ enrichment of carbon isotopic values leads to highest $\delta^{13} \mathrm{C}$ values of the time series. Consequently, the stalagmite shows a tripartite partition as shown in the $\delta^{18} \mathrm{O}$ VPDB versus $\delta^{13} \mathrm{C}$ VPDB diagram (Fig. 6) with the base featuring the most depleted $\delta^{18} \mathrm{O}$ and $\delta^{13} \mathrm{C}$ values before $\sim 126 \mathrm{ka}$. A rapid shift towards higher isotopic values between $\sim 126$ and $\sim 120 \mathrm{ka}$ and a third segment, from $\sim 120$ to $\sim 83 \mathrm{ka}$, show rather stable $\delta^{13} \mathrm{C}$ and $\delta^{18} \mathrm{O}$ values except for the $93-87 \mathrm{ka}$ period characterized by a change to lower isotopic values for oxygen and higher values for carbon.

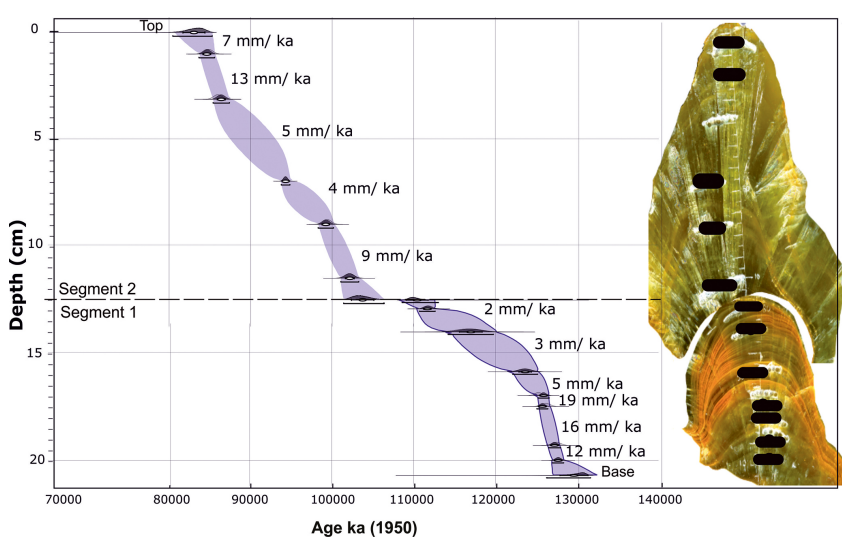

Figure 4. Growth rate of the stalagmite with respect to distance (in $\mathrm{cm}$ ) from the top, using OxCal Bayesian statistics model between two consecutive dates except in the middle part where a discontinuity (hiatus) is identified. 


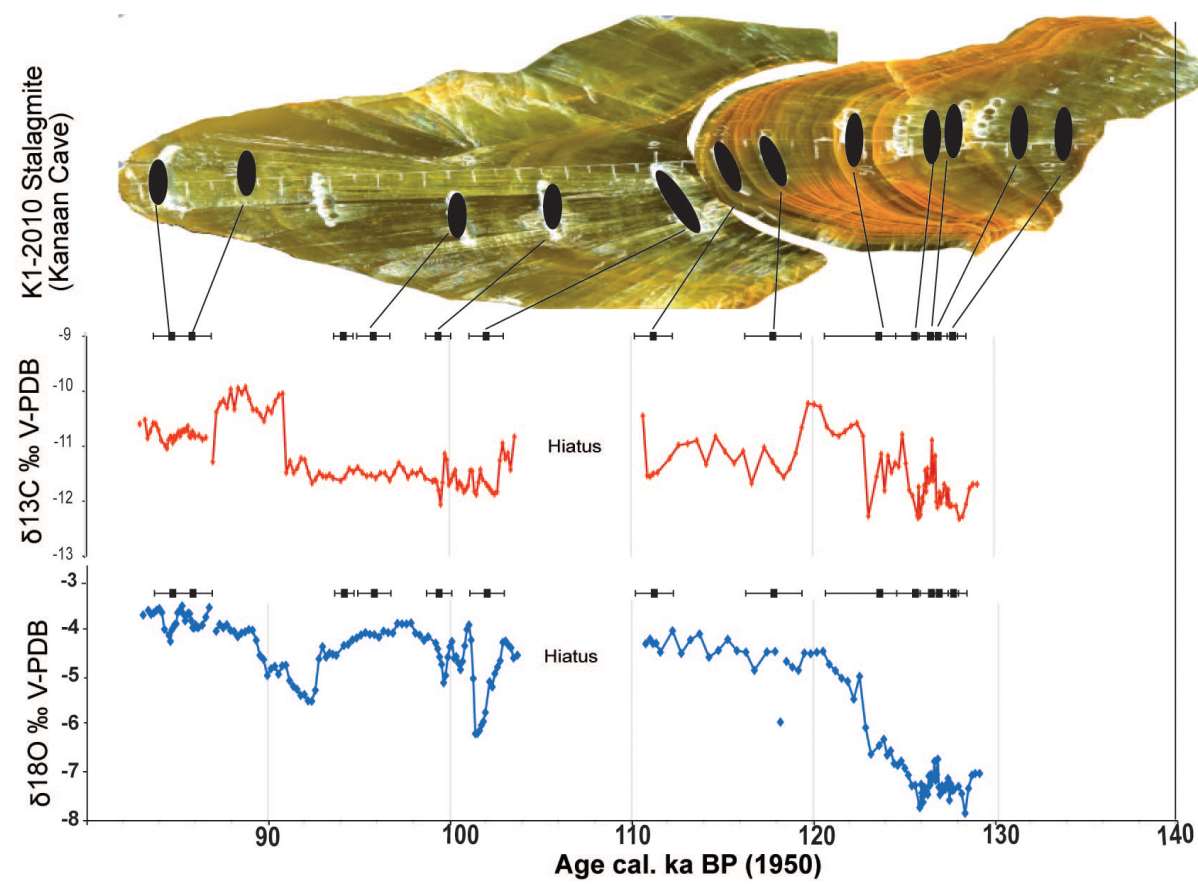

Figure 5. $\delta^{18} \mathrm{O}$ and $\delta^{13} \mathrm{C}$ profiles (values are in \%o VPDB) of samples microdrilled along the growth axis of the K1-2010 stalagmite (Kanaan Cave, Lebanon).

\section{Discussion}

\subsection{Integrated climatic interpretation of the speleothem proxies}

Speleothem growth is conditioned by effective precipitation and $\mathrm{CO}_{2}$ concentration, controlled mainly by the bio-activity of the soil and consequently by the temperature (Baker and Smart, 1995; Dreybrodt, 1988; Genty et al., 2006). Therefore speleothem growth is typically associated with warm and humid conditions with sufficient rainfall to maintain dripwater flow, whereas low speleothem growth rates or hiatuses tend to indicate cold or dry conditions (Bar-Matthews et al., 2003), or possibly flooding. The lower part of the stalagmite contains several clayey layers that may indicate either short dry periods or periods during which the speleothem was covered with mud or muddy water (Fig. 3). The fact that apart from these muddy layers the speleothem does not show any change in crystal aspect or change in porosity suggests that these layers may be better explained by sudden events perturbing slightly the speleothem deposition rather than a significant increase in aridity or drop in temperature. Previous studies in southern Europe (Drysdale et al., 2005; Zanchetta et al., 2007) and in the eastern Levant (Bar-Matthews et al., 2003; Frumkin et al., 2000; Verheyden et al., 2008) have shown that most of the carbon in speleothem calcite is derived from soil $\mathrm{CO}_{2}$ (Genty et al., 2001). The $\delta^{13} \mathrm{C}$ is thus most likely to be controlled by biogenic soil $\mathrm{CO}_{2}$ productivity (Gascoyne, 1992; Hellstrom et al., 1998; Genty et al., 2006) associated with vegetation density, which regulates soil $\mathrm{CO}_{2}$ content via root respiration, photosynthetic and microbial activity. The changes in carbon isotopic composition $\left(\delta^{13} \mathrm{C}\right)$ of speleothems in the Levant are thus linked to changes in precipitation with periods of low rainfall inducing sparse vegetation and a lower contribution of "light" organic carbon in the speleothem resulting in higher $\delta^{13} \mathrm{C}$ value (Frumkin et al., 2000). The low values for $\delta^{13} \mathrm{C}$ in the $\mathrm{K} 1$ 2010 around $\sim 128 \mathrm{ka}$ are indicative of a $100 \% \mathrm{C} 3$ vegetation profile, with relatively high soil productivity suggestive of rather mild and humid conditions.

A discontinuity (D2) is observed in the first segment (Fig. 3) and is estimated to occur between $\sim 110$ and $\sim 103 \mathrm{ka}$ by extrapolating the growth rates of each segment towards the discontinuity (D2). This hiatus could be of local origin as it is associated with a major change in the speleothem orientation (Nehme et al., 2015). A striking decrease in the growth rate to $5 \mathrm{~mm} \mathrm{ka}^{-1}$ before the speleothem tilted seems to start after $126 \mathrm{ka}$, before the end of the LIG (Cheng et al., 2009). Additional U-series dates are necessary to better constrain the age of the change in growth rate.

The middle part shows a higher growth rate $\left(9 \mathrm{~mm} \mathrm{ka}^{-1}\right)$ from $\sim 103$ to $\sim 99.1$ ka during the ensuing interstadial (MIS $5 \mathrm{c})$. A general decrease in growth rate ( 5 to $7 \mathrm{~mm} \mathrm{kyr}^{-1}$ ) followed from $\sim 99.1$ to $\sim 83 \mathrm{ka}$ but with an unusual rapid increase in growth rate $\left(13 \mathrm{~mm} \mathrm{ka}^{-1}\right)$ occurred from $\sim 86$ to $\sim 84$ ka during MIS 5b (Fig. 4). The carbon isotope signal shifts slightly to more positive values around $\sim 126-121 \mathrm{ka}$ and has the most positive values after $\sim 92 \mathrm{ka}$, indicating a 
gradual degradation of the soil coverage or change in vegetation type or density at the beginning of MIS $5 \mathrm{~d}$.

Unravelling the factors controlling the $\delta^{18} \mathrm{O}$ signal in a speleothem can be more complex (McDermott, 2004; Fairchild et al., 2006; Lachniet, 2009). The pattern of $\delta^{18} \mathrm{O}$ changes in K1-2010 stalagmite is slightly different from the $\delta^{13} \mathrm{C}$, particularly the difference in the amplitude of changes between $\sim 126$ and $120 \mathrm{ka}$, and from 120 to $83 \mathrm{ka}$.

Speleothem $\delta^{18} \mathrm{O}$ is controlled by both the calcite precipitation temperature (Kim and O'Neil, 1997) and seepage water $\delta^{18} \mathrm{O}$ (Lachniet, 2009). The general consensus in recent years is that the principal driver of speleothem $\delta^{18} \mathrm{O}$ variations through time is change in rainfall $\delta^{18} \mathrm{O}$ (McDermott, 2004), which are forced by (i) condensation temperatures, (ii) rainfall amount (Dansgaard, 1964); (iii) shifts in vapour source $\delta^{18} \mathrm{O}$, or (iv) different air-mass trajectories (Rozanski et al., 1993). Until now, low speleothem $\delta^{18} \mathrm{O}$ values in the Levant region were associated with wetter conditions, while high speleothem $\delta^{18} \mathrm{O}$ was generally ascribed to drier periods with lower rainfall amounts (Bar-Matthews, 2014; Verheyden et al., 2008). Important changes in $\delta^{18} \mathrm{O}$ may, however, also have been linked to changes in the source of the water vapour and/or changes in storm tracks (Frumkin et al., 1999; Kolodny et al., 2005; McGarry et al., 2004). From $\sim 126$ to $\sim 120 \mathrm{ka}$, the abrupt $3.2 \%$ increase in $\delta^{18} \mathrm{O}$ values suggests an important change to drier conditions. The growth rate of the stalagmite gradually falls from a high rate $\left(19 \mathrm{~mm} \mathrm{ka}^{-1}\right)$ between $126.7 \pm 1.0$ and $126.3 \pm 0.9 \mathrm{ka}$, decreasing to $5 \mathrm{~mm} \mathrm{ka}^{-1}$ between $126.3 \pm 0.9$ and $123.5 \pm 1.6 \mathrm{ka}$, and to $3 \mathrm{~mm} \mathrm{ka}^{-1}$ between $123.4 \pm 1.6$ and $117.7 \pm 3.0 \mathrm{ka}$ (Fig. 4). This gradual drop in growth rate most probably indicates a change towards drier conditions in agreement with the increase in $\delta^{18} \mathrm{O}$ values. Global sea levels reached 6 to $9 \mathrm{~m}$ above present sea level during the LIG (Dutton and Lambeck, 2012), an elevation peak that could not be responsible for the observed high amplitude of the $\delta^{18} \mathrm{O}$ change in the $\mathrm{K} 1$ speleothem. Another mechanism is a change in the composition and source of water vapour reaching the site. Studies of the eastern (EM), central, and western Mediterranean marine core records show evidence of reduced sea-surface $\delta^{18} \mathrm{O}$ during the onset of the Sapropel 5 event of $\sim 2 \%$ o (e.g. Kallel et al., 1997, 2000; Emeis et al., 2003; Rohling et al., 2002; Scrivner et al., 2004; Ziegler et al., 2010; Grant et al., 2012) and a recovery of the same amount at the end of S5 deposition around $\sim 121 \mathrm{ka}$ (Grant et al., 2012), with a commensurate increase in the $\delta^{18} \mathrm{O}$ of the EM water. Hence, a more ${ }^{18} \mathrm{O}$-enriched sea surface of $\sim 2 \%$ at the end of the sapropel event would cause an increase in vapour $\delta^{18} \mathrm{O}$, leading to enrichment in the isotopic composition of the recharge waters reaching the cave. In the Levant, moisture source was interpreted as one of the drivers for the $\delta^{18} \mathrm{O}$ signal in speleothems from Soreq Cave (Bar-Matthews et al., 2003) related to S5 (128-121 ka; Grant et al., 2012).

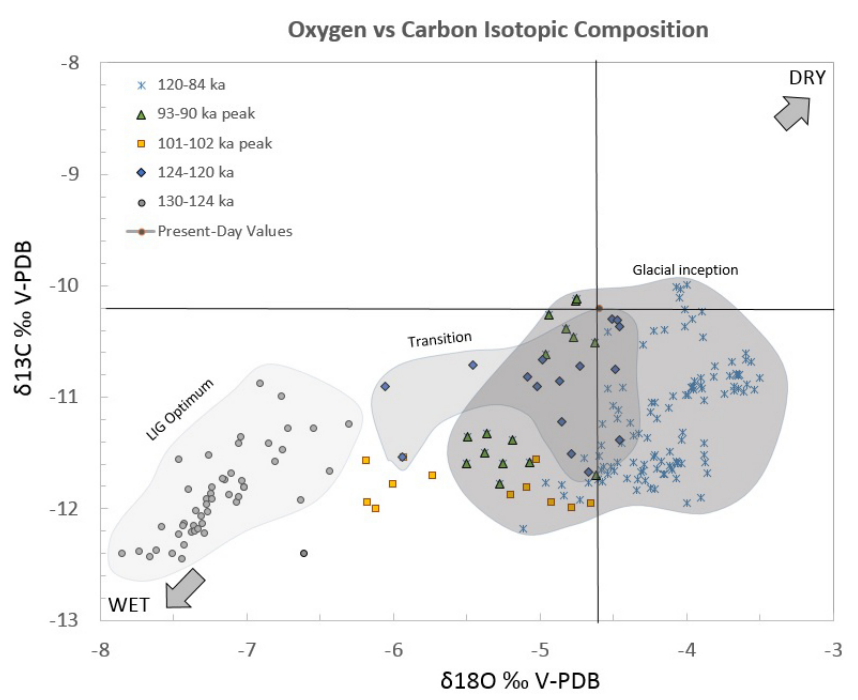

Figure 6. Oxygen versus carbon stable isotopic composition (values are in \%o VPDB) of samples microdrilled along the growth axis of the K1-2010 stalagmite (Kanaan Cave, Lebanon). The presentday $\delta^{18} \mathrm{O}$ value for the precipitated calcite was calculated using the Kim and O'Neil (1997) equilibrium equation. The $\delta^{13} \mathrm{C}$ value was obtained from the Holocene $\delta^{13} \mathrm{C}$ mean value of Jeita Cave (Verheyden et al., 2008). This cave, located just $20 \mathrm{~km}$ to the north, has a very similar climate, vegetation geology, soil type, and altitude (98 m a.s.1.) to Kanaan Cave.

After $\sim 120 \mathrm{ka}$, the $\delta^{18} \mathrm{O}$ increased to an average of $\sim-4.3 \%$, suggesting less depleted precipitation was reaching the cave until $\sim 84 \mathrm{ka}$. This long-term $\delta^{18} \mathrm{O}$ enrichment, interrupted by a short and moderate $\delta^{18} \mathrm{O}$ decrease during the S4 event, marks the Northern Hemisphere glacial inception (Fig. 6). This increase in $\delta^{18} \mathrm{O}$ is driven by several mechanisms. Once cause, the "ice volume effect", can lead to a higher sea water $\delta^{18} \mathrm{O}$ by $1.1 \%$ during glacial periods together with an increase in $\delta^{18} \mathrm{O}$ of speleothem calcite due to drop in temperature of up to $\sim 8^{\circ} \mathrm{C}$ (Frumkin et al., 1999; Bar-Matthews et al., 2003; Kolodny et al., 2005; McGarry et al., 2004). However, the change in the $\mathrm{K} 1$ speleothem $\delta^{18} \mathrm{O}$ records occurs after the gradual variation in the global interglacial-glacial changes at Termination II, suggesting a stronger influence of other mechanisms. A second possible driver for increased $\delta^{18} \mathrm{O}$ is related to changes in wind direction, with more continental trajectories leading to more enriched $\delta^{18} \mathrm{O}$ water vapour reaching the cave. In the southern Levant, Frumkin et al. (1999) and Kolodny et al. (2005) related $\delta^{18} \mathrm{O}$ signal increase during glacial periods to a southward migration of the westerlies associated with the highpressure zone over the northern European ice sheet and thus pushing wind trajectories further south over North Africa. The growth rate (Fig. 3) of the stalagmite after $\sim 120 \mathrm{ka}$ is the lowest of the entire profile (between 2 and $7 \mathrm{~mm} \mathrm{ka}^{-1}$ ) except for the periods between $84.8 \pm 1.1$ and $85.9 \pm 1.1 \mathrm{ka}$ and between $102 \pm 1.1$ and $99.3 \pm 0.9 \mathrm{ka}$. The first period has a 
growth rate of $13 \mathrm{~mm} \mathrm{ka}^{-1}$, indicating a wet pulse that could correspond to the pre-sapropel 3 event (Ziegler et al., 2010). The latter period has a moderate growth rate of $9 \mathrm{~mm} \mathrm{ka}^{-1}$ indicating a wet pulse, which coincides with the S4 event. The discontinuity (D2), between $\sim 110.6$ and $\sim 103.6 \mathrm{ka}$, is probably linked to local factors such as change in the percolation route or the tilting of the stalagmite's axis due to the floor suffusion beneath the block on which the speleothem grew.

\subsection{Palaeoclimate variability in MIS 5}

\subsubsection{An "early humid LIG"}

Speleothem oxygen, carbon, and growth proxies from sample K1-2010 indicate an initial relatively warm and humid period at $\sim 129 \mathrm{ka}$ - the beginning of speleothem deposition - which extended until $\sim 126 \mathrm{ka}$ (Fig. 7). This early humid LIG matches the timing of the eastern Mediterranean Sea S5 event (Ziegler at al., 2010; Grant et al., 2012) with high summer insolation (Berger and Loutre, 1991). In southern Europe, an early commencement of full interglacial conditions was dated at $129 \pm 1 \mathrm{ka}$ in Corchia Cave speleothems (Drysdale et al., 2005). In the northern Levant, the pollen records in Yammouneh palaeolake demonstrate the presence of temperate oaks during the early LIG (Develle et al., 2011), indicating sufficient humidity to enable forests to develop. More efficient moisture retention together with developed forest landscapes and intense groundwater circulation in northern Lebanon prevailed during the LIG. These warm and wet conditions are in agreement with similar periods identified in the Lake Van lacustrine sequence (Litt et al., 2014; Shtokhete et al., 2014) in northeastern Turkey and with speleothem proxies from the Soreq and Peqiin caves (Ayalon et al., 2002; Bar-Matthews et al., 2003) in southwestern Israel.

\subsubsection{The $126 \mathrm{ka}$ change}

The pattern of $\delta^{18} \mathrm{O}$ depletion from sample $\mathrm{K} 1-2010$ records a remarkable change between $126.3 \pm 0.9$ and $\sim 120.3 \mathrm{ka}$ (interpolated) along with an unstable enrichment pattern of the $\delta^{13} \mathrm{C}$ and the $\delta^{18} \mathrm{O}$ (Fig. 5). However, the poor chronological resolution of this part of the K1-2010 speleothem record precludes the identification of any seasonality pattern at the end of the LIG, as seen in the Yammouneh lacustrine record in northern Lebanon (Develle et al., 2011; Gasse et al., 2015).

The K1-2010 $\delta^{18} \mathrm{O}$ profile undergoes a dramatic change around $\sim 126 \mathrm{ka}$, the timing of which is very close to the onset of the isotopic enrichment of the water source in the eastern Mediterranean Sea during the S5 event ( 128-121 ka). The onset of the $\delta^{18} \mathrm{O}$ enrichment in the $\mathrm{K} 1-2010$ isotopic record coincides with the onset of the $\delta^{18} \mathrm{O}_{\mathrm{G} . r u b e r}$ enrichment (Fig. 7) in core LC21 (Grant et al., 2012) and at ODP Site 967 (Emeis et al., 2003). Despite differences in dating resolution between marine core records and speleothems, the shift in $\mathrm{K} 1-2010 \delta^{18} \mathrm{O}$ values around $\sim 126 \mathrm{ka}$ demonstrates a major source-driven change during the eastern Mediterranean S5 event. Several studies (Rohling et al., 2002, 2015a; Schmiedl et al., 2003; Scrivner et al., 2004) suggest a coincidence between cooling and enhanced aridity around the Mediterranean, and the interruption of the insolation-driven monsoon maximum for a millennial-scale episode during the last interglacial S5. Schmiedl et al. (2003) argue that this episode marked the onset of a regional climate deterioration following the peak (early S5) of the last interglacial. In that case, this regional climate deterioration began at $\sim 126 \mathrm{ka}$ ( Fig. 7), using the S5 timing of Grant et al. (2012) and with the assumed linear sedimentation rate through S5 (Rohling et al., 2002). The KI-2010 isotopic profile confirms this and provides a precise chronology of the change, taking place between $126.3 \pm 0.9 \mathrm{ka}$ and $\sim 120.3 \mathrm{ka}$ (interpolated). However, the amplitude of the $\delta^{18} \mathrm{O}$ enrichment in the K1-2010 stalagmite from 126 to $120 \mathrm{ka}$ totals $\sim 3.2 \%$ o and is much higher than the amplitude of the $\delta^{18} \mathrm{O}_{\mathrm{G} . r u b e r}$ enrichment $(\sim 2 \%$ ) in the eastern Mediterranean sea (Grant et al., 2012). This would be explained by Sapropel events in the EMS and their derivative processes during the S5 event (Ziegler et al., 2010): the source effect is thus a major driver for the $\delta^{18} \mathrm{O}$ values change in continental records, but other derivative factors of the $\mathrm{S} 5$ event contributed in the $\delta^{18} \mathrm{O}$ change in K1-2010 record such as the rainfall amount, the temperature, or changes in the wind trajectories.

With the additional U-Th datings and new records of Soreq Cave (Grant et al., 2012), the K1-2010 $\delta^{18} \mathrm{O}$ profile indicates that this major change occurred in phase with other continental records in the Levant region, moving the interpretation based on previous age model (Verheyden et al., 2015). The $\delta^{18} \mathrm{O}$ and $\delta^{13} \mathrm{C}$ change in the $\mathrm{K} 1-2010$ profiles lasted 6000 years, started gradually, and then continued more rapidly, ending at $\sim 120.3 \mathrm{ka}$ (interpolated). The initial pattern of the change from $\sim 126$ to $\sim 122 \mathrm{ka}$ suggests more gradual $\delta^{18} \mathrm{O}$ enrichment than the change in the Soreq Cave $\delta^{18} \mathrm{O}$ records. Nonetheless, the rapid pattern of the $\delta^{18} \mathrm{O}$ changes well recorded by the Soreq Cave record in that period could not be observed in the Kanaan Cave record due to the poor resolution of this part of the $\mathrm{K} 1$ speleothem with the occurrence of short hiatuses (mud layers). A similar gradual variation but over a larger timescale was demonstrated in the Yammouneh palaeovegetation signal, where the transition seems to be more progressive than in other eastern Mediterranean records. In the southern Levant, the oxygen and carbon isotopic record in the Peqiin and Soreq caves suggest an abrupt but later enrichment signal around $\sim 118 \mathrm{ka}$ (BarMatthews et al., 2003). This change was shifted to $\sim 120.5 \mathrm{ka}$ (Grant et al., 2012) using a more refined U-Th chronology (Fig. 7).

\subsubsection{The glacial inception}

After $\sim 120.3 \mathrm{ka}$, a more enriched $\delta^{18} \mathrm{O}$ profile indicates the end of warm and wet conditions of the LIG. The onset of 

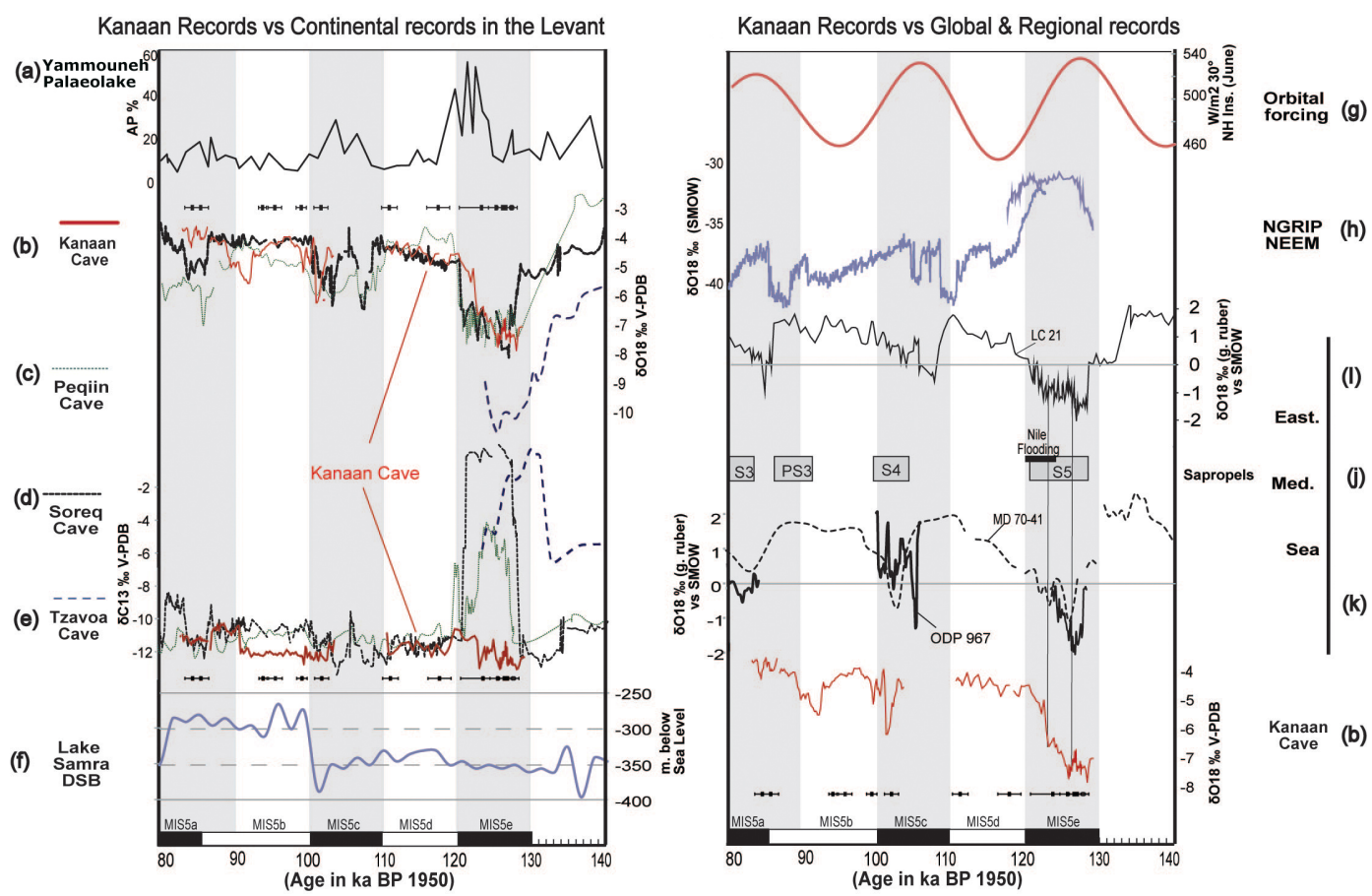

Figure 7. Left panel: Kanaan Cave $\delta^{18} \mathrm{O}$ and $\delta^{13} \mathrm{C}$ profiles compared to continental records in the Levant. From north to south of the Levant: (a) Yammouneh AP \%, north Lebanon (Gasse et al., 2015); (b) Kanaan carbon and oxygen isotopic profile (this study); (c) Peqiin Cave (Bar-Matthews et al., 2003); (d) Soreq Cave (Grant et al., 2012); (e) Tzavoa Cave (Vaks et al., 2006); and (f) lake Samra palaeolevels in the Dead Sea basin (Waldmann et al., 2009). Right panel: Kanaan Cave $\delta^{18}$ O profile compared to global and regional records in the eastern Mediterranean Basin: (g) summer insolation at 30 $\mathrm{N}$ and orbital eccentricity forcing (Berger and Loutre, 1991); (h) NGRIP-NEEM, indicating the volume of the Arctic ice sheet (NGRIP Members, 2004; + NEEM community members, 2013); (i) eastern Mediterranean $\delta^{18} \mathrm{O}_{\mathrm{G} . r u b e r}$ in core LC21 (Grant et al., 2012); (j) Mediterranean sapropel events (Ziegler et al., 2010) and the Nile flooding event (Scrivner et al., 2004); and (l) EMS Mediterranean $\delta^{18} \mathrm{O}_{\text {G.ruber }}$ in ODP Site 967 and in MD 70-41 site resampled at 1 kyr intervals (Emeis et al., 2003).

glacial conditions as indicated in several continental records in the eastern Mediterranean (Fig. 7) shows gradual climate deterioration into the glacial inception period before MIS 4. The isotopic response of K1-2010 to the glacial inception is recorded synchronously at $\sim 120 \mathrm{ka}$ in both $\delta^{18} \mathrm{O}$ and $\delta^{13} \mathrm{C}$ signals, but while the $\delta^{18} \mathrm{O}$ decreases rapidly along with a shift to a moderate growth rate, especially in response to the wet pulses during the $\mathrm{S} 4$ event, the $\delta^{13} \mathrm{C}$ shows a more gradual evolution. This can be explained by the fact that a rainfall- and mostly source-driven $\delta^{18} \mathrm{O}$ signal is rapidly transmitted to K1-2010 speleothem, whereas the inertia and gradual change in the $\delta^{13} \mathrm{C}$ signal reflect a long-term deterioration of the soil and biopedological activity above the cave. On a regional scale, the Yammouneh palaeovegetation signal indicates expanded steppic vegetation cover after $\sim 120 \mathrm{ka}$ (Develle et al., 2011). In the southern Levant, a gradual $\delta^{13} \mathrm{C}$ and $\delta^{18} \mathrm{O}$ enrichment, except for the wet pulses during the S4 and S3 events, until the end of MIS 5 indicates a general climate degradation that could be related to less rainfall derived from the Mediterranean moisture source (Ayalon et al., 2002; Bar-Matthews et al., 2003) or to changes in wind circulation pattern (Kolodny et al., 2005; Lisker et al., 2010). Further south in the Negev region, a different climatic regime from the northern Levant is recorded from speleothems and lacustrine records. Speleothem growth rates decreased after MIS 5c (Vaks et al., 2006), with less rainfall from the Mediterranean Sea reaching Tzavoa Cave (northern Negev). Speleothem records from caves located further south in the Negev Desert (Vaks et al., 2010) along with the Mudawara palaeolake records in southern Jordan showed a wet pulse during MIS 5a, related more to rainfall originating from the Indian monsoon (Petit-Maire et al., 2010). Moreover, Lake Samra records in the DSB are less out of phase with Levantine records further north than suggested for the last $20 \mathrm{kyr}$ (Cheng et al., 2015). The DSB records, recently investigated with a higher chronological resolution (Neugebauer et al., 2015) than previous studies (Waldmann et al., 2009), show minor high levels during MIS 5c and 5a. These wet pulses indicate though wet periods but with smaller amplitude than the wet phase in the northern Levant. The climate picture of the DSB during the glacial inception is related probably to local factors influenced by the Judean rain shadow (Vaks et al., 2006, 2013) and, together with other continental records further south, invokes climatic variations driven by the monsoon system (Torfstein et al., 2015) and its boundary shifts 
(Parton et al., 2015; Bar-Mathews, 2014) or by the North Atlantic and Mediterranean climates (Neugebauer et al., 2015).

\section{Conclusions}

A dated MIS 5 stalagmite record (129-84 ka) from Kanaan Cave, Lebanon, demonstrates the potential of stalagmite records for palaeoclimate reconstruction in the northern Levant. The K1-2010 model age coupled with growth rates and isotopic data provide a more precise record of the climatic changes that occurred during the last interglacial and on into the glacial inception period.

The K1-2010 speleothem record indicate a very wet early LIG and during the LIG optimum at the global scale, and is in agreement with warm and humid conditions demonstrated in other speleothem and lacustrine records from the Mediterranean. The K1-2010 isotope record and growth rate curves clearly demonstrate an important change from $126.3 \pm 0.9$ to $120.3 \mathrm{ka}$ (interpolated). The change seems to be driven mainly by a "source" effect, reflecting the $\delta^{18} \mathrm{O}$ Mediterranean Sea surface water composition and the EM isotopic increase at $\sim 126 \mathrm{ka}$ during the S5 event. Other factors such as the rainfall amount, the temperature or the wind trajectories might have contributed as a second-order factor to the $\delta^{18} \mathrm{O}$ change from 126 to $120 \mathrm{ka}$. This change sets the onset of the regional climate deterioration following the peak (early S5) of the last interglacial over the Levant region. However, the climatic change as recorded in the K1-2010 isotopic record could be more gradual than the changes identified in the Soreq and Peqiin speleothem records.

After $\sim 120 \mathrm{ka}$, enriched oxygen and carbon profiles in K1-2010 document the end of the LIG humid phase. The change in isotopic composition from 122 to $120 \mathrm{ka}$ is driven by a reduction in rainfall originating from the Mediterranean Sea, coupled with a long-term change in the $\delta^{18} \mathrm{O}$ composition of the EM surface waters. The onset of glacial inception conditions, as indicated in several continental records in the Levant, is signified by a gradual climatic deterioration until the full glacial conditions of MIS 4. A short, wet phase $(\sim 103-100 \mathrm{ka})$ at the end of the S4 event is indicated by increased water circulation into Kanaan Cave causing faster speleothem growth rates, sediment flushing, subsidence, and speleothem tilting. The climatic scheme suggested from K1-2010 isotopic profiles and growth rates is in overall agreement with Yammouneh palaeolake records in northern Lebanon, and with the Soreq and Peqiin speleothem records. However, the K1-2010 record shows different amplitude patterns with continental records located further south, although it does not show a clear out-of-phase climate variability during MIS 5 as demonstrated for the last 20000 years by the Jeita speleothem record (Cheng et al., 2015).

\section{The Supplement related to this article is available online} at doi:10.5194/cp-11-1785-2015-supplement.
Acknowledgements. This study was funded by the mobility fellowship programme of the Belgian Federal Scientific Policy (BELSPO), co-funded by the Marie Curie Actions of the European Commission. We acknowledge EDYTEM Laboratory (UMR-5204 CNRS) and Saint-Joseph University for making stalagmites of Kanaan Cave available for analyses during this study. We would like to thank the support of ALES (Association Libanaise d'Etudes Spéléologiques) members who accompanied us during field trips. Farrant and Noble publish with the approval of the Executive Director, British Geological Survey. We thank Thomas Goovaerts for sampling preparation, Daniel Condon for assisting with the uranium series analyses and Kevin De Bont for assisting in water analyses. We also thank the anonymous reviewers for their constructive comments and reviews.

Edited by: D. Fleitmann

\section{References}

Andersen, M. B., Stirling, C. H., Potter, E. K., Halliday, A. N., Blake, S. G., McCulloch, M. T., Ayling, B. F. and O'Leary, M.: High-precision U-series measurements of more than 500000 year old fossil corals, Earth Planet. Sc. Lett., 265, 229-245, 2008.

Arz, H. W., Lamy, F., Patzold, J., Muller, P. J., and Prins, M.: Mediterranean moisture source for an early-Holocene humid period in the northern Red Sea, Science, 300, 118-121, 2003.

Ayalon, A., Bar-Matthews, M., and Kaufman, A.: Climatic conditions during marine isotopic stage 6 in the Eastern Mediterranean region as evident from the isotopic composition of speleothems: Soreq Cave, Israel, Geology, 30, 303-306, 2002.

Ayalon, A., Bar-Matthews, M., Frumkin, A., and Matthews, A.,: Last Glacial warm events on Mount Hermon: the southern extension of the Alpine karst range in the east Mediterranean, Quaternary Sci. Rev., 59, 43-56, 2013.

Baker, A. and Smart, P. L.: Recent flowstone growth rates: field measurements in comparison to theoretical predictions, Chem. Geol., 122, 121-128, 1995.

Bar-Matthews, M.: History of Water in the Middle East and North Africa, in: Treatise on Geochemistry, edited by: Holland H. D. and Turekian K. K., Second Edition, Oxford, Elsevier, 109-128, 2014.

Bar-Matthews, M., Ayalon, A., Kaufman, A., and Wasserburg, G. J.: The Eastern Mediterranean paleoclimate as a reflection of regional events: Soreq Cave, Israel, Earth Planet. Sc. Lett., 166, 85-95, 1999.

Bar-Matthews, M., Ayalon, A., and Kaufman, A.: Timing and hydrological conditions of Sapropel events in the Eastern Mediterranean, as evident from speleothems, Soreq Cave, Israel, Chem. Geol., 169, 145-156, 2000.

Bar-Matthews, M., Ayalon, A., Gilmour, M., Matthews, M., and Hawkesworth, C.: Sea-land isotopic relationships from planktonic foraminifera and speleothems in the Eastern Mediterranean region and their implications for paleorainfall during interglacial interval, Geochim. Cosmochim. Ac., 67, 3181-3199, 2003.

Bronk Ramsey, C.: Deposition models for chronological records, Quaternary Sci. Rev., 27, 42-60, 2008.

Berger, A. and Loutre, M. F.: Insolation values for the climate of the last 10 million years, Quaternary Sci. Rev., 10, 297-317, 1991. 
Cheddadi, R. and Rossignol-Strick, M.: Eastern Mediterranean Quaternary paleoclimates from pollen and isotope records of marine cores in the Nile cone area, Paleoceanography, 10, 291-300, 1995.

Cheng, H., Edwards, R. L., Broecker, W. S., Denton, G. H., Kong, X., Wang, Y., Zhang, R., and Wang, X.: Ice age terminations, Science, 326, 248-252, 2009.

Cheng, H., Sinha, A., Verheyden, S., Nader, F. H., Li, X. L., Zhang, P. Z., Yin, J. J., Yi, L., Peng, Y. B., Rao, Z. G., Ning Y. F., and Edwards R. L.: The climate variability in northern Levant over the past 20000 years, Geophys. Res. Lett., 42, 8641-8650, 2015.

Cuffey, K. M. and Marshall, S. J.: Substantial contribution to sealevel rise during the last interglacial from the Greenland ice sheet, Nature, 404, 591-594, 2000.

Dansgaard, W.: Stable isotopes in precipitation, Tellus, 16, 436468, doi:10.1111/j.2153-3490.1964.tb00181, 1964.

Develle, A. L., Gasse, F., Vidal, L., Williamson, D., Demory, F., Van Campo, E., Ghaleb, B., and Thouveny, N.: A 250 ka sedimentary record from a small karstic lake in the Northern Levant (Yammoûneh, Lebanon): Paleoclimatic implications, Palaeogeogr. Palaeoecol., 305, 10-27, 2011.

Dreybrodt, W.: Processes in karst systems, Springer-Verlag, New York, 288 pp., 1988.

Drysdale, R., Zanchetta, G., Hellstrom, J., Fallick, A., and Zhao, J.$\mathrm{X}$.: Stalagmite evidence for the onset of the Last Interglacial in southern Europe at $129 \pm 1 \mathrm{ka}$, Geophys. Res. Lett., 32, L24708, 2005.

Drysdale, R., Hellstrom, J., Zanchetta, G., Fallick A. E., Sánchez Goñi, M. F., Couchoud I., McDonald J., Maas, R., Lohmann, G., and Isola I.: Evidence for obliquity forcing of glacial Termination II, Science, 325, 1527-1531, 2009.

Drysdale, R. N., Zanchetta, G., Hellstrom, J. C., Fallick, A. E., McDonald, J., and Cartwright, I.: Stalagmite evidence for the precise timing of North Atlantic cold events during the early last glacial, Geology, 35-1, 77-80, doi:doi:10.1130/G23161A.1, 2007.

Dutton, A. and Lambeck, K.: Ice volume and sea level during the last interglacial, Science, 337, 216-219, 2012.

Edwards, R. L., Chen, J. H., Ku, T. L., and Wasserburg, G. J.: Precise timing of the last interglacial period from massspectrometric determination of ${ }^{230} \mathrm{Th}$ in corals, Science, 236, 1547-1553, 1987.

Emeis K. C., Schulz H., Struck U., Rossignol-Strick M., Erlenkeuser H., Howell M. W., Kroon D., Mackensen A., Ishizuka S., Oba T., Sakamoto T., and Koizumi I.: Eastern Mediterranean surface water temperatures and $\delta^{18} \mathrm{O}$ during deposition of sapropels in the late Quaternary, Paleoceanography, 18, 1005-1029, 2003.

Emiliani, C.: Pleistocene temperatures, J. Geol., 63, 538-578, 1955.

Enzel, Y., Amit, R., Dayan, U., Crouvi, O., Kahana R., Ziv, B., and Sharon D.: The climatic and physiographic controls of the eastern Mediterranean over the late Pleistocene climates in the southern Levant and its neighboring deserts, Global Planet. Change, 60, 165-192, 2008.

Fairchild, I. J., Smith, C. L., Baker, A., Fuller, L., Spötl, C., Mattey, D., and McDermott, F.: Modification and preservation of environmental signals in speleothems, Earth Sci. Rev., 75, 105-153, 2006.
Frumkin, A., Ford, D. C., and Schwarcz, H.P .: Continental oxygen isotopic record of the last 170000 years in Jerusalem, Quatern. Res., 51, 317-327, 1999.

Frumkin, A., Ford, D. C., and Schwarcz, H.: Paleoclimate and vegetation of the Last Glacial cycles in Jerusalem from a speleothem record, Global Biogeochem. Cy., 14, 863-870, 2000.

Gascoyne, M.: Palaeoclimate determination from cave calcite deposits, Quaternary Sci. Rev., 11, 609-632, 1992.

Gasse, F., Vidal, L., Develle, A.-L., and Van Campo, E.: Hydrological variability in the Northern Levant: a 250 ka multi-proxy record from the Yammoûneh (Lebanon) sedimentary sequence, Clim. Past, 7, 1261-1284, doi:10.5194/cp-7-1261-2011, 2011.

Gasse, F., Vidal L., Van Campo, E., Demory, F., Develle, A.-L., Tachikawa, K., Elias, A., Bard, E., Garcia, M., Sonzogni., C., and Thouveny, N.: Hydroclimatic changes in northern Levant over the past 400000 years, Quaternary Sci. Rev., 111, 1-8, 2015.

Genty, D., Baker, A., and Vokal, B.: Intra- and inter-annual growth rate of modern stalagmites, Chem. Geol., 176, 191-212, 2001.

Genty, D., Blamart, D., Ouahdi, R., Gilmour, M., Baker, A., Jouzel, J., and Van-Exter, S.: Precise dating of Dansgaard-Oeschger climate oscillations in western Europe from stalagmite data, Nature, 421, 833-837, 2003.

Genty, D., Blamart, D., Ghaleb, B., Plagnes, V., Causse, C.h., Bakalowicz, M., Zouari, K., Chkir, N., Hellstrom, J., Wainer, K., and Bourges, F.: Timing and dynamics of the last deglaciation from European and North African $\mathrm{d}{ }^{13} \mathrm{C}$ stalagmite profilescomparison with Chinese and South Hemisphere stalagmites, Quaternary Sci. Rev., 25, 2118-2142, 2006.

Grant, K. M., Rohling, E. J., Bar-Matthews, M., Ayalon, A., Medina-Elizalde, M., Bronk Ramsey, C., Satow, C., and Roberts, A. P.: Rapid coupling between ice volume and polar temperature over the past $150 \mathrm{kyr}$, Nature 491, 744-747, 2012.

Hellstrom, J.: U-Th dating of speleothems with high initial ${ }^{230} \mathrm{Th}$ using stratigraphical constraint, Quat. Geochron., 1, 289-295, 2006.

Hellstrom, J., McCulloch, M., and Stone, J.: A detailed 31 000-year record of climate and vegetation change, from the isotope geochemistry of two New Zealand speleothems, Quaternary Res., 50, 167-178, 1998.

Heiss, J., Condon, D. J., McLean, N., and Noble, S. R.: ${ }^{238} \mathrm{U} /{ }^{235} \mathrm{U}$ systematics in terrestrial uranium-bearing minerals, Science, 335, 1610-1614, 2012.

Hendy, C. H.: The isotopic geochemistry of speleothems - I., The calculation of the effects of different modes of formation on the isotopic composition of speleothems and their applicability as palaeoclimatic indicators, Geochim. Cosmochim. Ac., 35, 801824, 1971.

Kallel, N., Duplessy, J.-C., Labeyrie, L., Fontugne, M., Paterne, M., and Montacer, M.: Mediterranean pluvial periods and sapropel formation during the last 200000 years, Palaeogeogr. Palaeoecol., 157, 45-58, 2000.

Kallel, N., Paterne, M., Duplessy, J.-C., Vergnaud-Grazzini, C., Pujol, C., Labeyrie, L., Arnold, M., Fontugne, M., and Pierre, C.: Enhanced rainfall in the Mediterranean region during the last sapropel event, Oceanol. Ac., 20, 697-712, 1997.

Kaufman, A., Wasserburg, G. J., Porcelli, D., Bar-Matthews, M., Ayalon, A., and Halicz, L.: U-Th isotope systematics from the Soreq Cave Israel and climatic correlations, Earth Planet. Sci Lett., 156, 141-155, 1998. 
Kim, S. T. and O'Neil, J. R.: Equilibrium and nonequilibrium oxygen isotope effects in synthetic carbonates, Geochim. Cosmochim. Ac., 61-16, 3461-3475, 1997.

Kopp, R. E., Simons, F. J., Mitrovica, J. X., Maloof, A. C., and Oppenheimer, M.: Probabilistic assessment of sea level during the last interglacial stage, Nature, 462, 863-867, 2009.

Kolodny, Y., Stein, M., and Machlus, M.: Sea-rain-lake relation in the Last Glacial East Mediterranean revealed by d18O-d13C in Lake Lisan aragonites, Geochim. Cosmochim. Ac., 69, 40554060, 2005.

Lachniet, M. S.: Climatic and environmental controls on speleothem oxygenisotope values, Quaternary Sci. Rev., 28, 412-432, 2009.

Lisker, S., Vaks, A., and Bar-Matthews, M.: Late Pleistocene palaeoclimatic and palaeoenvironmental reconstruction of the Dead Sea area (Israel), based on speleothems and cave stromatolites, Quaternary Sci. Rev., 29, 1201-1211, 2010.

Litt, T., Pickarski, N., Heumann, G., Stockhecke, M., and Tzedakis, P. C.: A 600000 year long continental pollen record from Lake Van, eastern Anatoloia (Turkey), Quaternary Sci. Rev., 104, 3041, 2014.

Lourens, L. J., Antonarakou, A., Hilgren, F. J., Van Hoof, A. A. M., Vergnaud-Grazzini, C., and Zachariasse W. J.: Evaluation of the Plio-Pleistocene astronomical timescale, Paleoceanography, 11, 391-413, 1996.

McDermott, F.: Paleo-climate reconstruction from stable isotope variations in speleothems: a review, Quaternary Sci. Rev., 23, 901-918, 2004.

McGarry, S., Bar-Matthews, M., Matthews, A., Vaks, A., Schilman, B., and Ayalon, A.: Constraints on hydrological and paleotemperature variations in the Eastern Mediterranean region in the last $140 \mathrm{ka}$ given by thedD values of speleothem fluid inclusions, Quaternary Sci. Rev., 23, 919-934, 2004.

Moller, T., Schultz, H., Hamann, Y., Dellwig, O., and Kucera, M.: Sedimentology and geochemistry of an exceptionally preserved last interglacial sapropel S5 in the Levantine Basin (Mediterranean Sea), Mar. Geol., 291-294, 34-48, 2012.

NEEM community members: Eemian interglacial reconstructed from a Greenland folded ice core, Nature 493, 489-494, 2013.

Nehme, C., Verheyden, S., Noble, S., Farrant, A., and Delannoy, J. J.: Contribution of an accurate growth rate reconstruction of a stalagmite from the Kanaan Cave-Lebanon to the understanding of humidity variations in the Levant during the MIS 5, Geol. Belg., 18, 2-4, 102-108, 2015.

Neugebauer, I., Schwab, M. J., Waldmann, N. D., Tjallingii, R., Frank, U., Hadzhiivanova, E., Naumann, R., Taha, N., Agnon, A., Enzel, Y., and Brauer, A.: Hydroclimatic variability in the Levant during the early last glacial $(\sim 117-75 \mathrm{ka})$ derived from micro-facies analyses of deep Dead Sea sediments, Clim. Past Discuss., 11, 3625-3663, doi:10.5194/cpd-11-3625-2015, 2015.

North Greenland Ice Core Project members: High-resolution climate record of Northern Hemisphere climate extending into the Last Interglacial period, Nature, 431, 147-151, 2004.

Otto-Bliesner, B. L., Rosenbloom, N., Stone, E. J., McKay, N. P., Lunt, D. J., Brady, E. C., and Overpeck, J. T.: How warm was the Last Interglacial? New model-data comparisons, Philos. T. R. Soc. A, 371, 1-20, 2013.

Parton, A., White, T. S., Parker, A. G., Breeze, P. S., Jennings, R., Groucutt, H. S., and Petraglia, M. D.: Orbital-scale climate vari- ability in Arabia as a potential motor for human dispersals, Quaternary Int., 382, 82-97, 2015.

Petit-Maire, N., Carbonel, P., Reyss, J.L., Sanlaville, P., Abed, A., Bourrouilh, R., Fontugne, M., and Yasin, S.: A vast Eemian palaeolake in Southern Jordan $\left(29^{\circ} \mathrm{N}\right)$, Global Planet. Change, 2, 72, 368-373, 2010.

Republic of Lebanon: Policy Note on Irrigation Sector Sustainability, Report No. 28766-LE, the World Bank, Middle-East and North Africa Region, 2003.

Rohling, E. J., Cane, T. R., Cooke, S., Sprovieri, M., Bouloubassi, I., Emeis, K. C., Schiebel, R., Kroon, D., Jorissen, F. J., Lorre, A., and Kemp, A. E. S.: African monsoon variability during the previous interglacial maximum, Earth Planet Sci. Lett., 202, 6175, 2002.

Rohling, E. J., Sprovieri, M., Cane, T. R., Casford, J. S. L., Cooke, S., Bouloubassi, I., Emeis, K. C., Schiebel, R., Hayes, A., Jorissen, F. J., and Kroon, D.: Reconstructing past planktic foraminiferal habitats using stable isotope data: a case history for Mediterranean sapropel S5, Mar. Micropaleontol., 50, 89-123, 2004.

Rohling, E. J., Sprovieri, M., Cane, T., Casford, J. S. L., Cooke, S., Bouloubassi I., Emeis K. C., Schiebel R., Rogerson M., Hayes A., Jorissen F. J., and Kroon D.: Reconstructing past planktic foraminiferal habitats using stable isotope data: a case history for Mediterranean sapropel S5, Mar. Micropaleontol., 50, 89-123, 2015a.

Rohling, E. J., Marino, G., and Grant, K. M.: Mediterranean climate and oceanography, and the periodic development of anoxic events (sapropels), Earth Sci. Rev., 143, 62-97, 2015 b.

Rossignol-Strick, M. and Paterne, M.: The Holocene climatic optimum and pollen records of sapropel 1 in the Eastern Mediterranean, 9000-6000 BP, Quaternary Sci. Rev., 18, 515-530, 1999.

Rozanski, K., Araguas, L., and Gonfiantini, R.: Isotopic patterns in modern global precipitation, in: Climate Change in Continental Isotopic Record, Geophysical Monograph Series, Washington DC, AGU, 78, 1-37, 1993.

Saad, Z., Slim, K., Ghaddar, A., Nasreddine, M., and Kattan, Z., Composition chimique des eaux de pluie du Liban; Chemical composition of rain water in Lebanon, Journal Europeen d'Hydrologie, 31-32, 105-120, 2000.

Saaroni, H., Ziv, B., Bitan, A., and Alpert, P.: Easterly wind storms over Israel, Theor. Appl. Climatol., 59, 61-77, 1998.

Schmiedl, G., Mitschele, A., Beck, S., Emeis, K. C., Hemleben, C., Schultz, H., Sperling, M., and Weldeab, S.: Benthic foraminiferal record of ecosystem variability in the eastern Mediterranean Sea during times of sapropel S5 and S6 deposition, Palaeogeogr. Palaeoecol., 190, 139-164, 2003.

Scrivner, A. E., Vance, D., and Rohling, E. J.: New neodymium isotope data quantify Nile involvement in Mediterranean anoxic episodes, Geology, 32, 565-568, 2004.

Shackleton, N. J., Chapman, M., Sanchez Goni, M. F., Pailler, D., and Lancelot, Y.: The classic marine isotope substage 5e, Quaternary Res., 58, 14-16, 2002.

Shtokhete, M., Sturm, M., Brunner, I., Schmincke, H.-U., Sumita, M., Kipfer, R., Cukur, D., Kwiecien, O., and Anselmetti, F.: Sedimentary evolution and environmental history of Lake Van (Turkey) over the past 600000 years, Sedimentology, 61, 18301861, 2014. 
Torfstein A., Goldstein, S. L., Kushnir, Y., Enzel, Y., Haug, G., and Stein, M.: Dead Sea drawdown and monsoonal impacts in the Levant during the last interglacial, Earth Planet. Sci. Lett., 412, 235-244, 2015.

Vaks, A., Bar-Matthews, M., Ayalon, A., Schilman, B., Gilmour, M., Hawkesworth C. J., Frumkin A., Kaufman A., and Matthews A.: Paleoclimate reconstruction based on the timing of speleothem growth, oxygen and carbon isotope composition from a cave located in the "rain shadow", Israel, Quaternary Res., 59, 182-193, 2003.

Vaks, A., Bar-Matthews, M., Ayalon, A., Matthews, A., Frumkin, A., Dayan, U., Halicz, L., Almogi-Labin, A., and Schilman, B.: Paleoclimate and location of the border between Mediterranean climate region and the Saharo-Arabian desert as revealed by speleothems from the northern Negev Desert, Israel, Earth Planet. Sci. Lett., 249, 384-399, 2006.

Vaks, A., Bar-Matthews, M., Matthews A., Ayalon, A, and Frumkin, A.: Middle-Late Quaternary paleoclimate of northern margins of the Saharan-Arabian Desert: reconstruction from speleothems of Negev Desert, Israel, Quaternary Sci. Rev., 29, 2647-2662, 2013.

Van Geldern R. and Barth Johannes A. C.: Optimization of instrument setup and post-run corrections for oxygen and hydrogen stable isotope measurements of water by isotope ratio infrared spectroscopy (IRIS), Limnol. Oceanogr.-Methods, 10, 1024-1036, 2012.

Verheyden, S., Nader, F. H., Cheng, H. J., Edwards, L. R., and Swennen, R.: Paleoclimate reconstruction in the Levant region from the geochemistry of a Holocene stalagmite from the Jeita cave, Lebanon, Quaternary Res., 70, 368-381, 2008.
Verheyden S., Nehme C., Nader F. H., Farrant A. R., Cheng H., Noble S. R., Sahy D., Edwards R. L., Swennen R., Claeys P., and Delannoy, J. J.: X. The Lebanese speleothems and the Levant palaeoclimate, in: Quaternary Environments, edited by: Bar, J. Y. and Enzel, Y., Climate Change, and Humans in the Levant, Cambridge University Press, UK, accepted, 2015.

Waldmann, N., Stein, M., Ariztegui, D., and Starinsky, A.: Stratigraphy, depositional environments and level reconstruction of the last interglacial Lake Samra in the Dead Sea basin, Quaternary Res., 72, 1-15, 2009.

Wang, Y. J., Cheng, H., Edwards, R. L., An, Z. S., Wu, J. Y., Shen, C. C., and Dorale, J. A.: A high-resolution absolute-dated Late Pleistocene monsoon record from Hulu cave, China, Science, 294, 2345-2348, 2001

Zanchetta, G., Drysdale R. N., Hellstrom J. C., Fallick, A. E., Isola, I., Gaganf, M. K., and Pareschi, M. T.: Enhanced rainfall in the Western Mediterranean during deposition of sapropel S1: Stalagmite evidence from Corchia cave (Central Italy), Quaternary Sci. Rev., 26, 279-286, 2007.

Ziegler, M., Tuenter, E., Lourens, L. J.: The precession phase of the boreal summer monsoon as viewed from the eastern Mediterranean (ODP Site 968), Quaternary Sci. Rev. 29, 1481-1490, 2010. 